\title{
DAMPAK PENURUNAN TARIF IMPOR, INVESTASI DAN RELOKASI INDUSTRI BAN TERHADAP PERDAGANGAN KARET ALAM DAN BAN INDONESIA DI PASAR DUNIA
}

\author{
The Impact of Import Tariff Reduction, Investment and Rellocation of Tire \\ Industries on Indonesian's Natural Rubber and Tire Trade in the World Market
}

\author{
Zainuddin ${ }^{1}$, Bonar Marulitua Sinaga ${ }^{2}$, Sri Hartoyo ${ }^{3}$ dan Erwidodo ${ }^{4}$ \\ ${ }^{1}$ Mahasiswa Program Doktor IImu Ekonomi Pertanian, Sekolah Pascasarjana IPB \\ ${ }^{2}$ Departemen Ekonomi Sumberdaya dan Lingkungan, Fakultas Ekonomi dan Manajemen, IPB \\ ${ }^{3}$ Departemen IImu Ekonomi, Fakultas Ekonomi dan Manajemen, IPB, Bogor, \\ Jawa Barat 16680, Indonesia \\ ${ }^{4}$ Pusat Kajian Sosial Ekonomi dan Kebijakan Pertanian, Badan Penelitian dan Pengembangan \\ Pertanian, Kementerian Pertanian, Republik Indonesia \\ Email: zainuddin.ubr@gmail.com
}

Naskah diterima: 01/07/2018; Naskah direvisi: 02/11/2018; Disetujui diterbitkan: 14/04/2019

Dipublikasikan online: 31/07/2019

\begin{abstract}
Abstrak
Penelitian ini bertujuan menganalisis dampak penurunan tarif impor karet alam dan ban, peningkatan investasi dan relokasi industri ban dari USA, Jepang, Republik Rakyat Tiongkok (RRT) ke Indonesia terhadap perdagangan karet alam dan ban Indonesia. Kajian ini menggunakan model sistem persamaan simultan. Deregulasi perdagangan melalui penurunan tarif impor ban telah meningkatkan ekspor karet alam Indonesia ke pasar Jepang dan RRT yang mendorong peningkatan produksi dan ekspor ban Indonesia. Kebijakan tersebut telah memberikan dampak tidak menguntungkan bagi ekspor karet alam Thailand dan Malaysia. Kombinasi antara penurunan tarif impor ban dengan tarif impor karet alam RRT memberikan dampak tidak menguntungkan terhadap produksi dan ekspor karet alam Indonesia ke pasar RRT dan tidak berdampak signifikan terhadap harga karet alam tingkat petani domestik. Selanjutnya peningkatan investasi dan relokasi industri ban dari USA, Jepang, RRT ke domestik memberikan dampak terhadap peningkatan produksi dan ekspor ban Indonesia, konsumsi karet alam domestik, peningkatan produksi dan harga karet alam di tingkat petani domestik. Perubahan positif neraca perdagangan juga terjadi ketika semakin besarnya peningkatan investasi dan relokasi industri ban ke domestik. Kajian ini merekomendasikan agar pemerintah dan asosiasi industri melakukan industrial lobbying ke negara-negara besar pelaku industri ban dunia khususnya Asia Timur dan USA dalam kerangka kerja sama PTA atau FTA.
\end{abstract}

Kata Kunci: Karet Alam, Ban, Perdagangan, Sistem Persamaan Simultan

\begin{abstract}
This study aims to analyze the impact of the reduction in import tariff on natural rubber and tires, increase investment and relocate of tire industry from the USA, Japan, China to Indonesia to trade in natural rubber and Indonesian tires. The analysis of the Indonesian natural rubber and tires trade used simultaneous equation system models. Trade deregulation through a reduction in tire import tariff had increased Indonesia's natural rubber exports to Japanese and Chinese markets, which has encouraged to increase Indonesian tire production. However, this policy had unfavorable impact on Thailand and Malaysia's natural rubber exports. The combination of the reduction in tire import tariff and the tariff for importing Chinese natural rubber had an unfavorable impact on the production and export of Indonesian natural rubber to the Chinese market and had a weak impact on the natural rubber prices of domestic farmers. Furthermore, increased investment and relocation of the tire industry from the USA, Japan, China to Indonesia had increased Indonesian tire production and exports,
\end{abstract}


domestic consumption of natural rubber, production and prices of natural rubber at the level of domestic farmers. A positive change in the trade balance also occurred when the increasing investment and relocation of the tire industry to the domestic market grew. This study recommended the government and industrial association to conduct industrial lobbying to big tire-industry players particularly in East Asia and USA under PTA and FTA Framework.

Keywords: Natural Rubber, Tire, Trade and Simultaneous Equations System

JEL Classification: F13, F17, Q17

\section{PENDAHULUAN}

Karet alam (natural rubber) dihasilkan dari pohon karet (hevea brasillensis). Karet alam memiliki sifat keelastisan, kekerasan, dan ketahanan (elasticity, harshness, and endurance) yang menjadikannya sebagai aspek komersial penting pada berbagai produk industri pengolahan karet. Pada tahun 2000 , produksi karet alam dari anggota Association of Natural Rubber Producing Contries (ANRPC, 2016) dan negara produsen lainnya mencapai 6,81 juta ton. 14 tahun kemudian naik hampir dua kali lipat sebesar 12,07 juta ton pada tahun 2014. Konsumsi karet alam dunia periode 2000 - 2014 juga naik hampir dua kali lipat yaitu dari 7,11 juta ton meningkat menjadi 12,16 juta ton tahun 2014 (IRSG, 2016). Negara produsen seperti Thailand, Indonesia, dan Vietnam lebih dominan mengekspor karet alam dibandingkan untuk konsumsi domestik, hanya Malaysia yang menunjukkan konsumsi domestik relatif lebih tinggi. Indonesia dan Thailand sangat mengandalkan kegiatan ekspor ke beberapa negara dengan jenis karet spesifikasi teknis seperti karet SIR (Standard Indonesia Rubber), karet SMR (Standard Malaysia Rubber) dan karet STR (Standard Thailand Rubber). Ekspor karet alam Indonesia digunakan sebagai bahan baku industri manufaktur karet negara pengimpor seperti AS, Jepang, RRT, Uni Eropa, dan lainnya. Sebaliknya Thailand mendominasi ekspor karet alam ke RRT dan Korea Selatan, namun patut dicatat bahwa lebih dari 2/3 (1,6 juta ton) ekspor karet alam Thailand ditujukan untuk pasar ekspor RRT. Bagi Indonesia, pasar ekspor RRT menempati urutan nomor tiga setelah pasar ekspor AS dan Jepang.

Perkembangan ekspor karet alam terkait dengan fluktuasi harga. Data historis contract future Singapore Commodity Exchange (SICOM) menunjukkan harga indikasi karet alam yang sering menjadi acuan di pasar fisik. Harga karet alam berupa intermediate goods mengalami kenaikan dari 1975 sampai puncaknya 
1980. Setelah itu terjadi penurunan harga hingga 1982. Harga karet alam menunjukkan stabil dari tahun 1982 sampai 1993. Periode 1993 sampai 1995, harga karet alam kembali meningkat sampai puncaknya tahun 1995, setelah itu terjadi penurunan harga hingga tahun 2001. Harga karet alam kembali meningkat dalam waktu cukup lama mulai tahun 2002 sampai tahun 2011. Puncak kenaikan harga karet alam terjadi pada tahun 2011 yang naik 8-9 kali lipat dari tingkat harga tahun 2002 untuk karet spesifikasi teknis dan 6-7 kali lipat untuk karet RSS3 (Rubber Smoke Sheet 3). Harga karet alam pada tahun 2011 adalah kenaikan harga tertinggi sepanjang sejarah perdagangan karet alam. Harga karet alam berdasarkan contract future SICOM bertransmisi ke pasar fisik karet. Harga FOB SIR20 dan RSS1 pada sejumlah pelabuhan (Belawan, Palembang, Priok) juga menunjukkan bergerak menaik hingga tahun 2011, setelah itu harga karet secara perlahan mengalami penurunan. Pergerakan harga FOB karet alam Indonesia serupa dengan pergerakan harga FOB di Malaysia untuk SMR20 dan Bulk Latex, dan Thailand untuk STR20 dan RSS3. Setelah tahun 2011 harga karet alam mengalami penurunan. Penurunan harga kemungkinan terkait dengan perlambatan ekonomi di negara-negara pengimpor karet alam dan penurunan harga minyak mentah dunia beberapa tahun sebelumnya.

Industri produk karet domestik berkembang seiring tumbuhnya ekspor produk ban dengan code HS 4011 (new pneumatictires of rubber) ke berbagai negara. Tren ekspor Indonesia terus meningkat selama periode 2000 sampai 2014. Namun dalam lima tahun terakhir ekspor tersebut (diukur dari nilai ekspor) mengalami penurunan ke sejumlah pasar ekspor. Pada periode yang sama impor produk karet oleh negara pengimpor besar menunjukkan tren yang menaik (UN Comtrade, 2016). Negara produsen karet alam hanya menempati ranking 6 sampai 12 negara eksportir terbesar produk karet, sedangkan ranking satu sampai lima ditempati oleh RRT, Jepang, AS, Jerman, dan Korsel. Disamping itu, ekspor produk tersebut dikenakan tarif escalation dengan variasi berbeda antar negara untuk melindungi industri sejenis di pasar domestik negara pengimpor. Negara importir melakukan praktek bea masuk terhadap impor ban dibanding impor komoditas karet alam. Pada 
Gambar 1 pasar ekspor karet AS tidak menerapkan bea masuk bagi karet alam, namun menerapkan bea masuk untuk ban dan produk karet lainnya mulai 0 sampai $9,3 \%$ periode 1996 sampai 2015. RRT sebagai negara importir terbesar dalam perdagangan karet alam dunia menerapkan bea masuk lebih ketat dengan tarif impor masuk dalam kisaran $20 \%$ sampai $38,9 \%$ untuk karet alam dan $8 \%$ sampai $23,5 \%$ untuk ban dan produk karet lainnya periode 1996 sampai 2015 (World Bank, 2017).

Arus perdagangan meningkat bila tarif impor ditekan pada tingkat minimal yang tidak memberatkan arus perdagangan (Chacholiades, 1978; Houck, 1992; Tweeten, 1992; Koo \& Kennedy, 2005). Pasar ekspor potensial untuk ban masih terdapat di beberapa negara baik di Asia, Amerika Latin, Eropa, dan lainnya namun masih terisolasi oleh bea masuk cukup besar sehingga kurang kompetitif dan tidak memperoleh akses pasar yang lebih besar. Kemungkinan peningkatan perdagangan dapat dicapai untuk ban melalui penurunan tarif impor, maka perlu dikaji dampak penurunan tarif impor ban di negara pengimpor terhadap perdagangan karet alam dan ban Indonesia di pasar dunia.

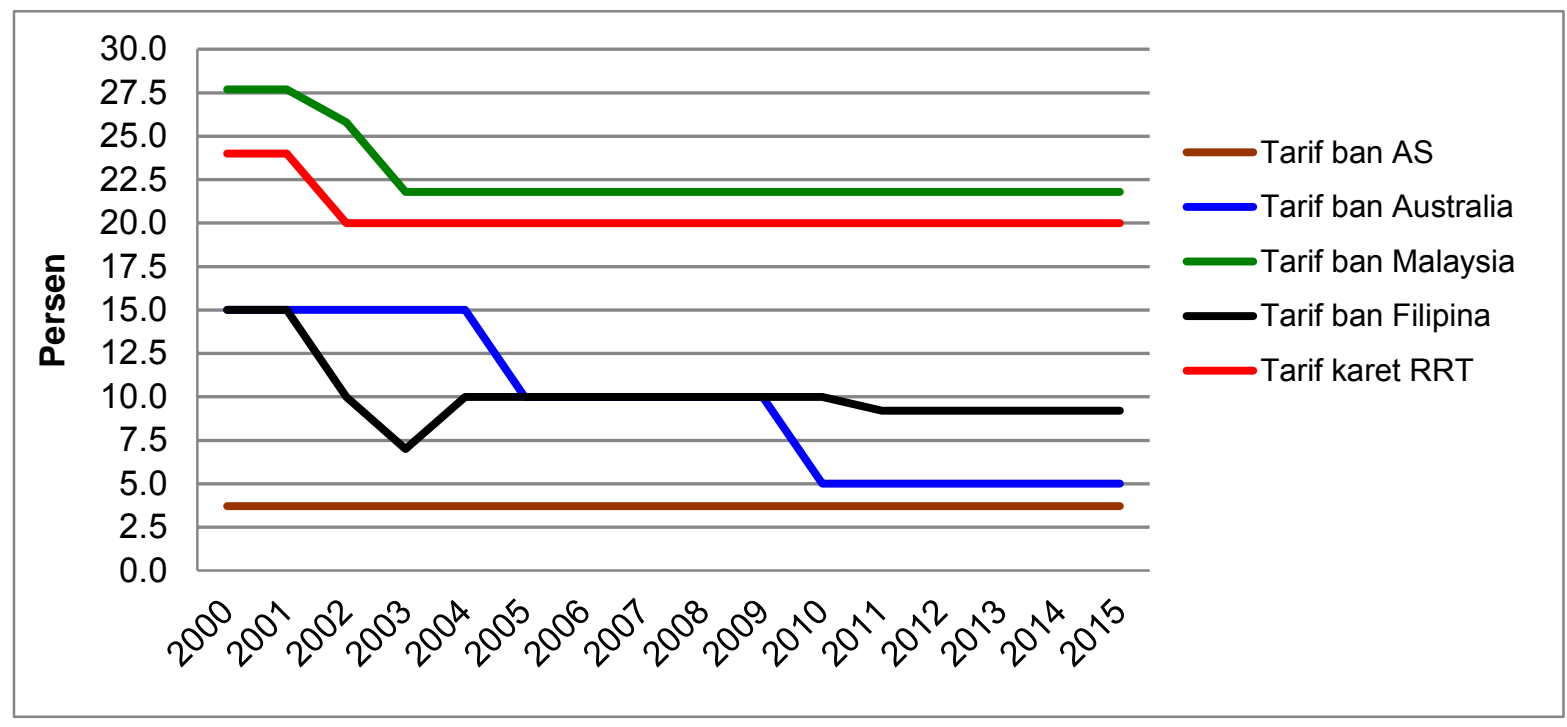

Gambar 1. Tarif Impor Karet Alam RRT dan Ban di USA, Australia, Malaysia dan Filipina

Sumber: WTO Secretariat (2017) 


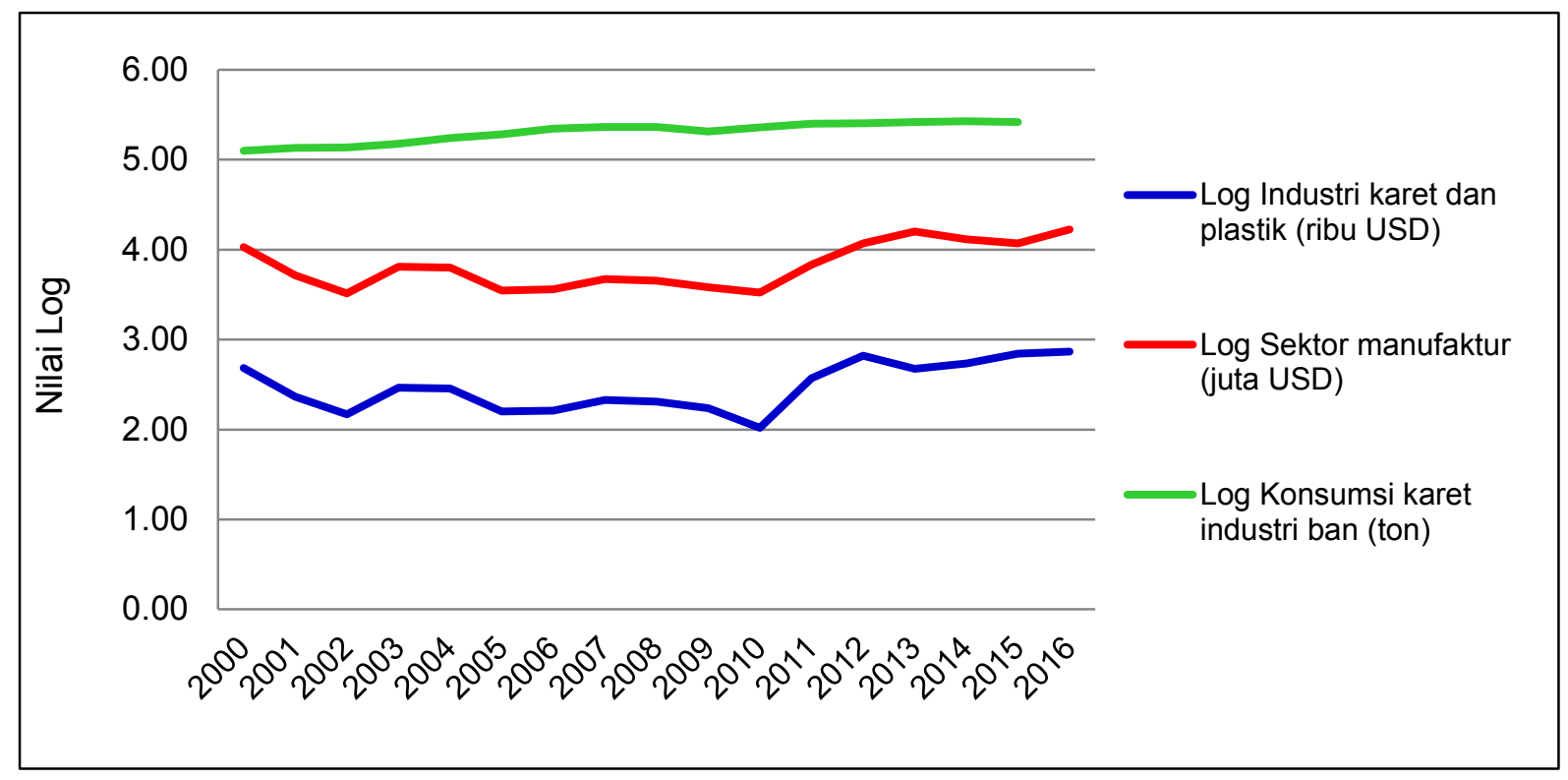

Gambar 2. Investasi Asing Sektor Manufaktur, Industri Karet dan Plastik serta Konsumsi Karet Alam oleh Industri Ban Indonesia

Sumber: BPS, BKPM, ASEAN, Kemenperin (2017), diolah

Perkembangan industri ban begitu lambat dibandingkan dengan negara produsen lainnya. Ekspor ban Indonesia hanya tumbuh rata-rata $14 \%$ dalam periode 2004-2017, sedangkan Thailand $43 \%$, RRT 33\%, Korsel 6\%, Jepang $0,7 \%$. Jepang dan Korsel mengembangkan industri ban ke berbagai negara seperti Thailand, RRT, Indonesia. Namun Indonesia tidak maksimal memanfaatkan situasi sebagai negara tujuan investasi industri ban (Comtrade, 2018). Pada Gambar 2 dapat dikaitkan pertumbuhan industri ban yang lambat terkait dengan rendahnya investasi baru. Selama sembilan tahun terakhir (2007-2015) produksi ban domestik didominasi oleh tujuh produsen besar yaitu Bridgestone, Sumi Rubber, Gajah Tunggal, Goodyear, Multistrada, Elang Perdana, dan Karet Deli. Akibatnya kenaikan produksi dan ekspor ban serta konsumsi karet alam domestik relatif rendah selama periode tersebut. Perkembangan yang lambat tersebut mendapat perhatian pemerintah setelah menerima masukan dari Asosiasi Produsen Ban Indonesia (APBI) perlunya pengamanan pasar domestik dari ban impor ilegal asal RRT dan India untuk mendorong tumbuhnya investasi baru industri ban domestik. Respon tersebut dalam bentuk Peraturan Menteri Perdagangan Nomor 77/MDAG/PER/11/ 2016 tentang ketentuan 
impor ban dan sekaligus mendorong industriawan negara lain untuk membangun pabrik ban di Indonesia. Peningkatan investasi diharapkan dapat meningkatkan produksi dan ekspor ban, konsumsi karet alam domestik dan terjadinya spillover produk karet lainnya. Oleh karena itu perlu dikaji dampak peningkatan investasi dan relokasi industri ke domestik terhadap perdagangan karet alam dan ban Indonesia di pasar dunia.

Tujuan penelitian adalah menganalisis dampak penurunan tarif impor, peningkatan investasi dan realokasi industri ke domestik terhadap perdagangan karet alam dan produk karet Indonesia di pasar dunia. Aspek perdagangan yang dianalisis adalah produksi, konsumsi, ekspor, impor, dan harga di negara eksportir dan importir.

\section{METODE}

Model yang dibangun untuk menganalisis dampak penurunan tarif impor ban mengikuti model strategi perdagangan (strategic trade model) yang telah secara luas digunakan dalam penelitian sebelumnya (Brander, 1995; Chilimoniuk, 2003; Reimer \& Stiegert, 2006). Produsen manufaktur ban Indonesia menawarkan produksi ke pasar domestik dan ke pasar ekspor di negara $j(j=$ USA, Jepang, Australia, Malaysia, Filipina). Pada saat yang sama produsen domestik manufaktur ban di negara $j$ juga menghasilkan produksi untuk pasar domestik negara $j$ dan mereka juga mengekspor ban ke negara lainnya. Produsen ban Indonesia dan produsen di negara $j$ berhadapan dengan downward sloping demand curve yang memungkinkan untuk memanfaatkan kekuatan pasar (market power) karena struktur kompetisi diasumsikan menyerupai oligopoli. Produsen ban Indonesia dan negara produsen lainnya memiliki keunggulan biaya dibandingkan dengan produsen sejenis di negara $j$ karena biaya input material dan upah tenaga kerja relatif lebih rendah, tetapi mengeluarkan biaya transportasi pelayaran dan bea masuk ke pasar ekspor di negara $j$. Negara $j$ memberlakukan tarif bea masuk bagi setiap jenis ban yang di impor. Secara ilustratif dapat digambarkan hubungan perdagangan ban antara Indonesia dengan negara $j$ (pengimpor) dan negara I (pesaing ekspor). Fungsi profit produsen domestik ban di negara $j$ adalah:

$\pi^{j}=P^{j}\left(Q^{j}\right) Q_{D}^{j}-C^{j}\left(Q_{D}^{j} ; X_{S}^{j}\right)-F^{j}$ 
$P^{j}$ adalah harga ban di negara $j, P^{j}($. adalah permintaan terbalik ban di negara $j, C^{j}($.$) dan F^{j}$ masing-masing biaya variabel dan biaya tetap ban di negara $j$. Kuantitas ban untuk pasar negara $j$ adalah jumlah dari produksi domestik $\left(Q_{D}^{j}\right)$ ditambah impor dari Indonesia $\left(Q_{i n a}^{j}\right)$ dan impor dari negara I $\left(Q_{l}^{j}\right)$. Fungsi profit untuk produsen manufaktur ban Indonesia yang mengekspor ke pasar negara $j$ adalah $\left(\pi_{\text {ina }}^{j}\right)$ :

$$
\begin{aligned}
\pi_{\text {ina }}^{j}= & \sum_{j=1}^{m-1}\left\{\frac{P^{j}\left(Q^{j}\right)}{\left(1+\tau_{a v}^{j}\right)} Q_{\text {ina }}^{j}+\sum_{j=m}^{n}\left[P^{j}\left(Q^{j}\right)-\right.\right. \\
& \left.\tau_{\text {st }}^{j}\right] Q_{\text {ina }}^{j}-C_{\text {ina }}^{j}\left(Q_{\text {ina }}^{j} ; X_{S}^{i n a} ; \operatorname{Tr}^{j}\right)- \\
& \left.F_{\text {ina }}^{j}\right\} \ldots \ldots \ldots \ldots \ldots \ldots \ldots \ldots \ldots \ldots \ldots \ldots \ldots \ldots \ldots \ldots \ldots \ldots \ldots \ldots
\end{aligned}
$$

dimana $Q^{j}=Q_{D}^{j}+Q_{\text {ina }}^{j}+Q_{l}^{j}+Q_{\text {Oth }}^{j}$

$\tau_{a v}^{j}$ dan $\tau_{s t}^{j}$ adalah masing-masing ad velorem dan specific tarif impor ban ke pasar negara $j . Q_{i n a}^{j}$ adalah jumlah atau volume ban Indonesia untuk pasar negara $j$. $\operatorname{Tr}^{j}$ adalah biaya transportasi pelayaran (cost of shipping) ke negara $j$. $X_{S}^{i n a}$ merupakan faktor penggeser penawaran ban Indonesia. Fungsi profit produsen manufaktur ban negara I yang mengekspor ke pasar di negara $j$ $\left(\pi_{l}^{j}\right)$ :

$$
\begin{aligned}
\pi_{l}^{j}= & \sum_{l=1}^{m-1}\left\{\frac{P^{j}\left(Q^{j}\right)}{\left(1+\tau_{a v}^{j}\right)} Q_{l}^{j}+\sum_{l=m}^{n}\left[P^{j}\left(Q^{j}\right)-\tau_{s t}^{j}\right] Q_{l}^{j}-\right. \\
& \left.C_{l}^{j}\left(Q_{l}^{j} ; X_{S}^{l} ; \operatorname{Tr}^{j}\right)-F_{l}^{j}\right\} \ldots \ldots \ldots \ldots \ldots \ldots \ldots \ldots \ldots \ldots \ldots \ldots
\end{aligned}
$$

dimana $Q^{j}=Q_{D}^{j}+Q_{\text {ina }}^{j}+Q_{l}^{j}+Q_{\text {oth }}^{j}$ $\tau_{a v}^{j}$ dan $\tau_{s t}^{j}$ adalah masing-masing ad valorem dan specific tarif impor ban ke pasar negara $j . Q_{l}^{j}$ adalah jumlah ban negara I untuk pasar negara j. $\operatorname{Tr}^{j}$ adalah biaya transportasi pelayaran (shipping cost) ke negara $j$. $X_{S}^{l}$ adalah faktor penggeser penawaran produk karet negara $I$. Diferensial fungsi profit (1), (2) dan (3) terhadap $Q_{D}^{j}, Q_{i d n}^{j}, Q_{l}^{j}$ diperoleh first order condition yang secara implisit merupakan reaksi atau fungsi respons pelaku perdagangan ban.

$$
\frac{\partial \pi^{j}}{\partial Q_{D}^{j}}=0, \quad \frac{\partial \pi_{i n a}^{j}}{\partial Q_{i n a}^{j}}=0, \quad \text { dan } \frac{\partial \pi_{l}^{j}}{\partial Q_{l}^{j}}=0
$$

Fungsi reaksi atau respons diatas mempunyai solusi yang unik bila fungsi tersebut downward sloping, fungsi biaya convex dan memenuhi kondisi turunan kedua atau fungsi profit concave dimana turunan keduanya negatif. Profit maksimum tercapai pada saat marjinal profit menurun. Untuk menganalisis dampak penurunan tarif impor terhadap jumlah ban di pasar ekspor negara $j$ dilakukan deferensial total fungsi reaksi atau respons diatas dan disusun dalam sistem tiga persamaan $(A x=b)$ berikut: 
$\left(\begin{array}{ccc}\frac{\partial \pi^{j}}{\partial Q_{D}^{j} \partial Q_{D}^{j}} & \frac{\partial \pi^{j}}{\partial Q_{D}^{j} \partial Q_{i n a}^{j}} & \frac{\partial \pi^{j}}{\partial Q_{D}^{j} \partial Q_{l}^{j}} \\ \frac{\partial \pi^{i n a}}{\partial Q_{\text {ina }}^{j} \partial Q_{D}^{j}} & \frac{\partial \pi^{i n a}}{\partial \dot{q}_{\text {ina }}^{j} \partial Q_{\text {ina }}^{j}} & \frac{\partial \pi^{i n a}}{\partial Q_{\text {ina }}^{j} \partial Q_{l}^{j}} \\ \frac{\partial \pi_{l}^{j}}{\partial Q_{l}^{j} \partial Q_{D}^{j}} & \frac{\partial \pi_{l}^{j}}{\partial Q_{l}^{j} \partial Q_{\text {ina }}^{j}} & \frac{\partial \pi_{l}^{j}}{\partial Q_{l}^{j} \partial Q_{l}^{j}}\end{array}\right)\left(\begin{array}{c}d Q_{D}^{j} \\ d Q_{\text {ina }}^{j} \\ d Q_{l}^{j}\end{array}\right)=\left(\begin{array}{c}\frac{\partial \pi^{j}}{\partial Q_{D}^{j} \tau_{a v}^{j}} d \tau_{a v}^{j}+\frac{\partial \pi^{j}}{\partial Q_{D}^{j} \tau_{s t}^{j}} d \tau_{s t}^{j} \\ \frac{\partial \pi^{j}}{\partial Q_{\text {ina }}^{j} a_{a v}^{j}} d \tau_{a v}^{j}+\frac{\partial \pi^{j}}{\partial Q_{i n a}^{j} \tau_{s t}^{j}} d \tau_{s t}^{j} \\ \frac{\partial \pi^{j}}{\partial Q_{l}^{j} l_{a v}^{j}} d \tau_{a v}^{j}+\frac{\partial \pi^{j}}{\partial Q_{l}^{j} \tau_{s t}^{j}} d \tau_{s t}^{j}\end{array}\right)$

Asumsi $|A|>0$ positif dan penggunaan Cramer'rule terhadap sistem persamaan (4) diperoleh perubahan suplai ekspor akibat perubahan tarif impor di negara $j$ berikut:

$\frac{d Q_{i n a}^{j}}{d \tau_{a v}^{j}}<0, \quad \frac{d Q_{i n a}^{j}}{d \tau_{s t}^{j}}<0, \frac{d Q_{l}^{j}}{d \tau_{a v}^{j}}<0, \quad \frac{d Q_{l}^{j}}{d \tau_{s t}^{j}}<0, \frac{d Q_{D}^{j}}{d \tau_{a v}^{j}}>0$, $\frac{d Q_{D}^{j}}{d \tau_{s t}^{j}}>0, \frac{d Q_{i n a}^{j}}{d \tau_{a v}^{h}}>0, \frac{d Q_{i n a}^{j}}{d \tau_{s t}^{h}}>0$

$\frac{d Q_{l}^{j}}{d \tau_{a v}^{h}}>0, \frac{d Q_{l}^{j}}{d \tau_{s t}^{h}}>0, \frac{d Q_{D}^{j}}{d \tau_{a v}^{h}}>0, \frac{d Q_{D}^{j}}{d \tau_{s t}^{h}}>0$,

dimana: $h \neq j$

Suatu penurunan tarif impor ban di negara $j$ akan meningkatkan kuantitas yang diekspor ke negara $j$ baik berasal dari Indonesia maupun dari negara $I$. Sebaliknya, penurunan tarif impor ban akan menurunkan kuantitas suplai ban oleh produsen domestik ke pasarnya masing-masing di negara j sebagai akibat dari naiknya suplai dari negara pengekspor ban. Efek penurunan tarif impor ban terhadap kuantitas suplai ban di negara $j$ tergantung mana yang lebih dominan antara efek langsung atau efek tidak langsung akibat penurunan tarif impor ban:

$$
\frac{d Q^{j}}{d\left(\tau_{a v}^{j-h}+\tau_{s t}^{h}\right)}=\left(\frac{d Q_{i n a}^{j-h}}{d \tau_{a v}^{j-h}}+\frac{d Q_{i n a}^{h}}{d \tau_{s t}^{h}}\right)+\left(\frac{d Q_{l}^{j-h}}{d \tau_{a v}^{j-h}}+\frac{d Q_{l}^{h}}{d \tau_{s t}^{h}}\right)+\left(\frac{d Q_{D}^{j-h}}{d \tau_{a v}^{j-h}}+\frac{d Q_{D}^{h}}{d \tau_{s t}^{h}}\right)
$$

\section{Peningkatan investasi pada industri ban domestik}

Teori investasi yang telah secara luas digunakan dalam penelitian empiris dimulai dari neoclassical theory, accelerator principle, sampai Tobin's $Q$ theory, dimana semuanya berdasarkan asumsi perilaku maksimisasi pengambil keputusan atau investor (Eklund, 2013). Sebagaimana Jorgenson (1963) bahwa produsen memaksimumkan keuntungan tiap periode dengan menggunakan modal pada tingkat optimal (optimal capital stock). Jika fungsi produksi mengikuti bentuk fungsi Cobb- Douglas berikut:

$\mathrm{Y}(\mathrm{t})=\mathrm{f}[\mathrm{K}(\mathrm{t}), \mathrm{L}(\mathrm{t}), \mathrm{R}(\mathrm{t})]=\mathrm{A} K^{\alpha} L^{\beta} R^{1-\alpha-\beta}$

atau mengikuti Jorgenson (1963) dalam bentuk persamaan keuntungan dapat dituliskan sebagai berikut: 


$$
\begin{aligned}
& \pi(t)=p(t)^{*} Y(t)-i(t)^{*} l(t)-w(t)^{*} L(t) \\
& -r(t)^{*} R(t)
\end{aligned}
$$

dimana $\mathrm{Y}$ adalah output, $\mathrm{K}$ adalah modal, $\mathrm{L}$ adalah tenaga kerja, dan $\mathrm{R}$ adalah bahan baku karet, $\pi$ adalah keuntungan, p adalah harga output, I adalah investasi, i adalah biaya modal, w adalah upah, dan $r$ adalah harga bahan baku karet. Dalam kondisi maksimisasi keuntungan, nilai sekarang (current value) yang diperoleh produsen bisa disusun dalam bentuk berikut (8):

$\mathrm{V}(0)=\operatorname{maks}_{z} \int_{0}^{\infty} \pi(t) e^{-s t} d t=$ $E_{Z} \int_{0}^{\infty}[\mathrm{p}(\mathrm{t}) \mathrm{Y}(\mathrm{t})-\mathrm{i}(\mathrm{t}) \mathrm{I}(\mathrm{t})-\mathrm{w}(\mathrm{t}) \mathrm{L}(\mathrm{t})-\mathrm{r}(\mathrm{t}) \mathrm{R}(\mathrm{t})] e^{-s t} d t$ dengan kendala : $\quad \mathrm{dK} / \mathrm{dt}=\mathrm{I}(\mathrm{t})-\delta \mathrm{K}(\mathrm{t})=$ $\dot{K}(\mathrm{t})$

dimana $E_{z}$ adalah kumpulan informasi yang tersedia bagi produsen dalam tiap periode. Untuk penyederhanaan dilakukan penghapusan notasi t dan $E_{Z}$. Kemudian untuk memaksimumkan nilai sekarang keuntungan yang diterima produsen dapat ditempuh dengan menggunakan fungsi Lagrange (d) :

$\oint=\mathrm{V}(0)+\int_{0}^{\infty} \lambda(\mathrm{I}-\delta \mathrm{K}-\dot{K}) e^{-s t} d t$

$\left.\oint=\int_{0}^{\infty}[\mathrm{pY}-\mathrm{iI}-\mathrm{wL}-\mathrm{rR}+\lambda(\mathrm{I}-\delta \mathrm{K})-\dot{\lambda} \mathrm{K})\right] e^{-s t} d t$ ..(9)

Fungsi Lagrange (d) dapat diubah menjadi bentuk fungsi current value Hamiltonian $\quad(\mathrm{H})$ sebagaimana Intrilligator (1971) dan Chiang (2000): $\mathrm{H}=\mathrm{pf}(\mathrm{K}, \mathrm{L}, \mathrm{R})-\mathrm{i} \mathrm{I}-\mathrm{wL}-\mathrm{rR}+\lambda(\mathrm{I}-\delta \mathrm{K}) \ldots(10)$ dimana $\lambda(t)$ adalah harga bayangan modal (shadow price of capital). Turunan pertama fungsi Hamiltonian (10) terhadap penggunaan modal $(\mathrm{K})$ diperoleh kondisi :

$\frac{\partial H}{\partial K}=p f_{K}-\lambda \delta=0$

Selanjutnya terdapat hubungan antara fungsi current value Hamiltonian $\left(H_{c}\right)$ dengan fungsi initial value Hamiltonian $(\widetilde{H})$ sehingga diperoleh suatu persamaan $\quad \lambda(\mathrm{t})=e^{s t} \mu(t)$ yang berfungsi sebagai variabel kontrol.

$-\frac{\partial H}{\partial K}=e^{s t} \dot{\mu}=\frac{\partial}{\partial t}\left[e^{s t} \mu(t)\right]=\frac{\partial \lambda}{\partial t}-s \lambda$

Persamaan (12) bisa ditulis kembali menjadi bentuk berikut ini:

$\frac{\partial i}{\partial t}=\frac{\partial \lambda}{\partial t} \quad$ dan $\quad \mathrm{i}=\lambda \quad$ sehingga

$p f_{K}=i\left[\delta+\mathrm{s}-\left(\frac{\partial i}{\partial t}\right) / \mathrm{i}\right]$

Sebelumnya Jorgenson

menggunakan notasi $\mathrm{c}=i\left[\delta+\mathrm{s}-\left(\frac{\partial i}{\partial t}\right) / \mathrm{i}\right]$ yang didefinisikan sebagai biaya penggunaan modal (user cost of capital) sehingga diperoleh hubungan antara tingkat pengembalian nilai marjinal modal dengan biaya penggunaan modal:

$p f_{K}=c$

Kembali ke fungsi produksi sebelumnya $f_{K}$ dan $\partial H / \partial K$ maka dapat diturunkan stok modal optimal $\left(K^{*}\right)$ :

$K^{*}=p \alpha Y / c$ 
Stok modal optimal tergantung dari harga output, output dan biaya penggunaan modal. Investasi yang dilakukan adalah perubahan dari stok modal optimal antar periode:

$I=[p \alpha Y / c]_{t}-[p \alpha Y / c]_{t-1}$

Peningkatan investasi untuk menuju stok modal optimal pada tiap periode akan meningkatkan output. Kenaikan output sebagai akibat dari peningkatan investasi akan mendorong semakin besar penggunaan input bahan baku dan input bahan penolong lainnya.

\section{Identifikasi dan Estimasi Model Empiris}

Model keterkaitan pasar perdagangan karet alam dan ban Indonesia di pasar dunia dibangun menggunakan sistem persamaan simultan karena saling terkait antara suplai, pemintaan dan harga di pasar domestik dan di pasar dunia sebagaimana peneliti sebelumnya Arunwarakorn, et al, 2017; NurHazirah, et al, 2016; Khin et al, 2014; dan Yusof,
1988. Model empiris terdiri dari 2 (dua) blok persamaan yaitu blok komoditas karet alam dan blok industri ban yang seluruhnya meliputi 40 persamaan perilaku (behavior equations) dan 19 persamaan identitas (identity equations). Identifikasi model menunjukkan total variabel dalam model dikurangi jumlah variabel dalam setiap persaman melebihi dari jumlah persamaan dikurangi satu. Hal ini menunjukkan model teridentifikasi secara overidentified dan model bisa diestimasi dengan two stage least squares method (Koutsoyiannis, 1977 dan Sitepu \& Sinaga, 2018). Model yang dibangun untuk menganalisis perdagangan karet alam dan ban (HS 4011) Indonesia di pasar dunia menggunakan simultaneous equations system karena pertimbangan perilaku yang saling terkait antara harga, permintaan, ekspor, impor dan produksi. Model ekonometrika yang dibangun dapat dilihat pada Tabel 1 dan 2. 
Tabel 1. Model Ekonometri Blok Karet Alam

\begin{tabular}{|c|c|c|}
\hline Produksi karet SIR Indonesia & QSIR & $\begin{aligned}= & a 0+a 1^{*} \text { PRUBFM + a2*RLIR + a3*PRRUB + } \\
& a 4^{*} \text { RPXCPO + a5*LQSIR }\end{aligned}$ \\
\hline Produksi karet alam Indonesia & QRUB & $=$ QSIR + QNSIR \\
\hline Penawaran karet SIR domestic & QSSIR & $=Q S I R-X S I R+M R U B$ \\
\hline Permintaan kare SIR domestik & QDSIR & $=\mathrm{DRUBRP}+\mathrm{MRUB}$ \\
\hline $\begin{array}{l}\text { Ekspor karet SIR Indonesia ke } \\
\text { pasar dunia }\end{array}$ & XSIR & $\begin{aligned}= & \text { XSIRUS + XSIRJP + XSIRCN + XSIRUE + } \\
& \text { XSIRALU + XSIROT }\end{aligned}$ \\
\hline Ekspor karet SIR Indonesia ke AS & XSIRUS & $\begin{aligned}= & \mathrm{b} 0+\mathrm{b} 1^{*} \text { D } 3 R P X S I R U S+\mathrm{b} 2^{*} \text { NTRPUSD }+ \\
& \mathrm{b} 3^{*} \text { TRCOSTUS + b4*QRSIR + b5ITRCD + } \\
& \mathrm{b} 6^{*} \text { LXSIRUS }\end{aligned}$ \\
\hline $\begin{array}{l}\text { Ekspor karet SIR Indonesia ke } \\
\text { Jepang }\end{array}$ & XSIRJP & $\begin{aligned}= & c 0+c 1^{*} \text { DRPXSIRJP }+c 2^{*} \text { NTRPUSD + c3*QSIR + } \\
& c 4^{*} \text { LXSTRJP + c5*ITRCD }+c 6^{*} \text { LXSIRJP }\end{aligned}$ \\
\hline $\begin{array}{l}\text { Ekspor karet SIR Indonesia ke } \\
\text { RRT }\end{array}$ & XSIRCN & $\begin{aligned}= & d 0+d 1^{*} R P X S I R C N+d 2^{*} \text { NTRPUSD + d3 }{ }^{*} Q S I R+ \\
& d 4^{*} X S T R C N+d 5^{*} \text { ITRCD + d6*LXSIRCN }\end{aligned}$ \\
\hline $\begin{array}{l}\text { Ekspor karet STR Thailand ke } \\
\text { pasar dunia }\end{array}$ & XSTR & $\begin{aligned}= & \text { XSTRUS + XSTRJP + XSTRCN + XSTRUE + } \\
& \text { XSTRALU + XSTROT }\end{aligned}$ \\
\hline Ekspor karet STR Thailand ke AS & XSTRUS & $\begin{aligned}= & \mathrm{e} 0+\mathrm{e} 1^{*} \text { DRPXSTR }+\mathrm{e} 2^{*} \text { NTBATUSD }+ \\
& \text { e } 3^{*} \text { QRUBTHA }+\mathrm{e} 4^{*} \text { TRCOSTUS }+\mathrm{e} 5^{*} \text { SHRXSIRUS } \\
& +\mathrm{e} 6^{*} \text { LXSTRUS }\end{aligned}$ \\
\hline $\begin{array}{l}\text { Ekspor karet STR Thailand ke } \\
\text { Jepang }\end{array}$ & XSTRJP & $\begin{aligned}= & f 0+f 1^{*} \text { DRPXSTR + f2*QRUBTHA + } \\
& \text { f3*NTBATUSD + f4*SHRXSIRJP + f5*ITRCD + } \\
& \text { f6* LXSTRJP }\end{aligned}$ \\
\hline Ekspor kare & XSTRCN & $\begin{aligned}= & g 0+g 1^{*} \text { LRPXSTR + g2*NTBATUSD + } \\
& g 3^{*} \text { QRUBTHA + g4*SHRXSIRCN + g5*ITRCD + } \\
& g 6^{*} \text { LXSTRCN }\end{aligned}$ \\
\hline $\begin{array}{l}\text { Ekspor karet SMR Malaysia ke } \\
\text { pasar dunia }\end{array}$ & XSMR & $=$ XSMRUS + XSMRJP + XSMRCN + XSMROT \\
\hline t SMR Malaysia ke AS & XSMRUS & $\begin{aligned}= & h 0+h 1^{*} \text { DRPXSMR + h2*L2QRUBMAL + } \\
& h 3^{*} \text { NTMYRUSD + h4 } 4^{*} \text { SHRXSIRUS + h5*LXSMRUS }\end{aligned}$ \\
\hline $\begin{array}{l}\text { Ekspor karet SMR Malaysia ke } \\
\text { Jepang }\end{array}$ & XSMRJP & $\begin{aligned}= & i 0+i 1^{*} \text { RPXSMR }+i 2^{*} \text { NTMYRUSD }+i 3^{*} \text { QRUBMAL } \\
& +i 4^{*} \text { SHRXSIRJP + i5*LXSMRJP }\end{aligned}$ \\
\hline Ekspor karet SMR Malaysia ke RRT & TXSMRCN & $\begin{aligned}= & j 0+j 1^{*} R P X S M R+j 2^{*} \text { DQRUBMAL }+ \\
& j 3^{*} \text { NTMYRUSD + j4*L3SHRXSIRCN + j5*ITRCD + } \\
& j 6^{*} \text { LXSMRCN }\end{aligned}$ \\
\hline SNR ke pasar dun & XTSNRW & $=$ XSIR + XSTR + XSMR + XTSNROT \\
\hline Ekses suplai karet TSNR dunia & EKSTSNRW & $=$ XTSNRW - MTSNRW \\
\hline Permintaan karet TSNR dunia & MTSNRW & $=$ MTSNRUS + MTSNRJP + MTSNRCN + MTSNRO \\
\hline Impor karet TSNR oleh AS & MTSNRUS & $\begin{aligned}= & \text { MSIRUSI + MSTRUST + MSMRUSM + } \\
& \text { MTSNRUSO }\end{aligned}$ \\
\hline Impor karet SIR Indonesia oleh AS & MSIRUSI & $\begin{aligned}= & \mathrm{k} 0+\mathrm{k} 1^{*} \mathrm{DRPMR} U \mathrm{BW}+\mathrm{k} 2^{*} \mathrm{R} \text { RDPUS + } \\
& \mathrm{k} 3^{*} \mathrm{NTRPUSD}+\mathrm{k} 4^{*} \mathrm{QRPUS}+\mathrm{k} 5^{*} \text { LMSIRUSI }\end{aligned}$ \\
\hline Impor karet STR Thailand oleh AS & MSTRUST & $\begin{aligned}= & 10+11^{*} \text { DRPMRUBW }+12^{*} \text { DRGDPUS + } 13^{*} \text { DQRPUS } \\
& +14^{*} \text { NTBATUSD }+15^{*} \text { SHRMSIRUS }+ \\
& 6^{*} \text { LMSTRUST }\end{aligned}$ \\
\hline Impor karet SMR Malaysia oleh AS & MSMRUSM & $\begin{aligned}= & m 0+m 1^{*} \text { RPMRUBW + m2*DGDPUS + } \\
& m 3^{*} \text { LNTMYRUSD + m4*QRPUS + } \\
& m 5^{*} \text { SHRMSIRUS + m6*LMSMRUSM }\end{aligned}$ \\
\hline TSNR oleh Jepang & MTSNR & $=$ MSIRJPI + MSTRJPT + MSMRJPM + MTSNRJPO \\
\hline $\begin{array}{l}\text { Impor karet SIR Indonesia oleh } \\
\text { Jepang }\end{array}$ & MSIRJPI & $\begin{aligned}= & n 0+n 1^{*} \text { RPMRUBW }+ \text { n2*DRGDPJP + } \\
& n 3^{*} \text { NTYEUSD + n4*DQRPJP + n5*ITRCD + n6* }+ \\
& n 7^{*} \text { LMSIRJPI }\end{aligned}$ \\
\hline $\begin{array}{l}\text { Impor karet STR Thailand oleh } \\
\text { Jepang }\end{array}$ & MSTRJPT & $\begin{aligned}= & 00+01^{*} \text { RPMRUBW }+02^{*} \text { DRGDPJP }+03^{*} \text { QRPJP } \\
& +04^{*} \text { NTYEUSD }+05^{*} \text { SHRMSIRJP }+ \\
& 06^{*} \text { LMSTRJPT }\end{aligned}$ \\
\hline
\end{tabular}




\begin{tabular}{|c|c|c|c|}
\hline $\begin{array}{l}\text { Impor karet SMR Malaysia oleh } \\
\text { Jepang }\end{array}$ & MSMRJPM & $=$ & $\begin{array}{l}\text { p0 + p1*D2RPMRUBW + p2*DRGDPJP + } \\
\text { p3*NTYEUSD + p4*D3QRPJP + p5*L3SHRMSIRJP } \\
+ \text { p6*ITRCD + p7*LMSMRJPM }\end{array}$ \\
\hline Impor karet TSNR oleh RRT & MTSNRCN & $=$ & $\begin{array}{l}\text { MSIRCNI + MSTRCNT + MSMRCNM + } \\
\text { MTSNRCNO }\end{array}$ \\
\hline $\begin{array}{l}\text { Impor karet SIR Indonesia oleh } \\
\text { RRT }\end{array}$ & MSIRCNI & $=$ & $\begin{array}{l}q 0+q 1^{*} \text { L3RPMRUBW +q2* } 2^{*} \text { RGDPCN + } \\
q 3^{*} N T Y N U S D+q 4^{*} Q R P C N+q 5^{*} T M R U B C N+ \\
q 6^{*} \text { LMSIRCNI }\end{array}$ \\
\hline Impor karet STR Thailand oleh RRT & ГMSTRCNT & $=$ & $\begin{array}{l}r 0+r 1^{*} \text { D2RPMRUBW + r2*RGDPCN + } \\
\text { r3*NTYNUSD + r4*DQRPCN + r5*TMRUBCN + } \\
\text { r6*L3SHRMSIRCN + r7 } 7^{*} \text { LMSTRCNT }\end{array}$ \\
\hline $\begin{array}{l}\text { Impor karet SMR Malaysia oleh } \\
\text { RRT }\end{array}$ & MSMRCNM & $=$ & $\begin{array}{l}\text { s0 + s1*L3PMRUBWNTR + s2*DRGDPCN + } \\
\text { s3*DQRPCN + s4*TMRUBCN + s5*L3SHRMRUBW } \\
+ \text { s6*LMSMRCNM }\end{array}$ \\
\hline $\begin{array}{l}\text { Harga karet alam tingkat petani } \\
\text { domestik }\end{array}$ & PRUBFM & $=$ & $\begin{array}{l}\text { t0 + t1 }{ }^{*} \text { DRPXSIR }+t 2^{*} Q S S I R+t 3^{*} \text { QDSIR + } \\
\text { t4*LPRUBFM }\end{array}$ \\
\hline Harga ekspor karet SIR Indonesia & RPXSIR & $=$ & $\begin{array}{l}\mathrm{u} 0+\mathrm{u} 1^{*} \mathrm{D} 2 \mathrm{RPMRUBW}+\mathrm{u} 2^{*} \mathrm{DMTSNRUS}+ \\
\mathrm{x} 3^{*} \mathrm{LRPXSIR}\end{array}$ \\
\hline Harga ekspor karet STR Thailand & RPXSTR & $=$ & $\begin{array}{l}\text { v0 + v1*DRPMRUBW + v2*D2MTSNRCN + } \\
\text { v3*LRPXSTR }\end{array}$ \\
\hline Harga ekspor karet SMR Malaysia & RPXSMR & $=$ & $\begin{array}{l}\text { w0 + w1*D2RPMRUBW + w2*DMTSNRCN + } \\
\text { w3*LRPXSMR }\end{array}$ \\
\hline Harga karet alam di pasar dunia & RPMRUBW & $=$ & $\begin{array}{l}x 0+x 1^{*} \text { XTSNRW }+x 2^{*} \text { MTSNRW }+x 3^{*} \text { PFUTRUB } \\
+x 4^{*} \text { LRPMRUBW }\end{array}$ \\
\hline $\begin{array}{l}\text { Harga kontrak berjangka karet di } \\
\text { Bursa Sicom }\end{array}$ & PFUTRUB & $=$ & $\begin{array}{l}\text { y0 + y1*D3XSIR + y2*D3XSTR + y3*DMTSNRCN } \\
+y 4^{*} \text { DQAUTW + y5*LPFUTRUB }\end{array}$ \\
\hline
\end{tabular}

\section{Tabel 2. Blok Industri Ban}

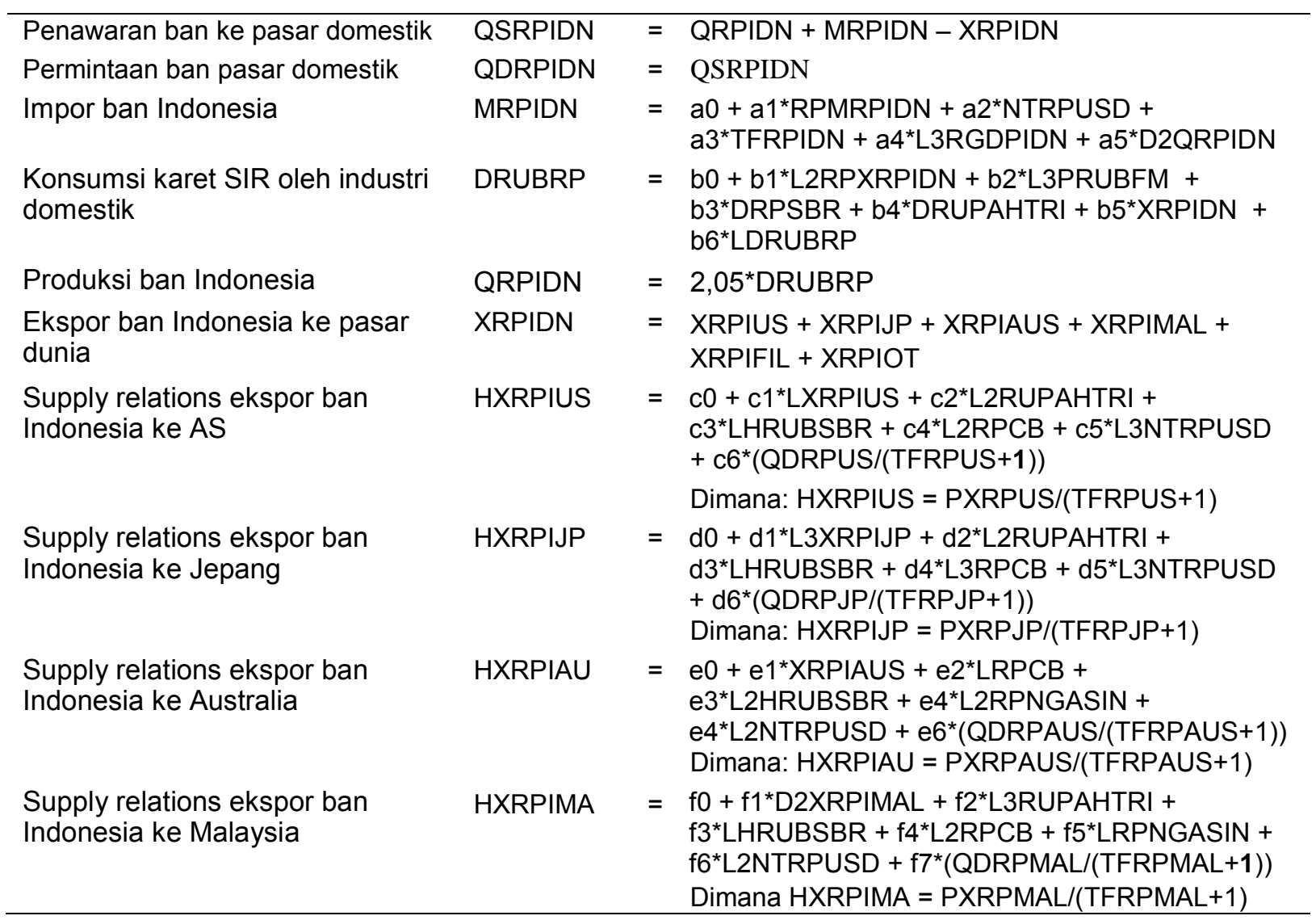




\begin{tabular}{|c|c|c|}
\hline $\begin{array}{l}\text { Supply relations ekspor ban } \\
\text { Indonesia ke Filipina }\end{array}$ & HXRPIFI & $\begin{aligned}= & g 0+g 1^{*} \text { D2XRPIFIL + g2*HRUBSBR + } \\
& g 3^{*} \text { L3RUPAHTRI }+\mathrm{g} 4^{*} \text { LRPNGASIN }+\mathrm{g} 5^{*} \text { LRPCB } \\
& +\mathrm{g} 6^{*} \text { L2NTRPUSD }+\mathrm{g} 7^{*}(\text { QDRPFIL/(TFRPFIL+1) } \\
& \text { Dimana HXRPIFI = PXRPFIL/(TFRPFIL+1) }\end{aligned}$ \\
\hline Ekspor ban Indonesia ke USA & XRPIUS & $\begin{aligned}= & \mathrm{h} 0+\mathrm{h} 1^{*} \text { L2HXRPIUS + h2*NTRPUSD + } \\
& \mathrm{h} 3^{*} \text { DRUPAHTRI + h4*LHRUBSBR + h5 }{ }^{*} \text { DQRPIDN } \\
& +\mathrm{h} 6^{*} \text { QRPUS }+\mathrm{h} 7^{*} \text { L3QAUTUS + h8*RGDPUS }+ \\
& \mathrm{h} 9^{*} T+\mathrm{h} 10^{*} \text { LXRPIUS }\end{aligned}$ \\
\hline Ekspor ban Indonesia ke Jepang & XRPIJP & $\begin{aligned}= & i 0+i 1^{*} \text { DHXRPIJP + i2*NTRPUSD } \\
& +i 3^{*} \text { L3RUPAHTRI + i } 4^{*} \text { L3HRUBSBR + } \\
& i 5^{*} \text { DQRPIDN + i6*DQRPIJP + i7*LQAUTJP + } \\
& i 8^{*} \text { D2RGDPJP + i9*LXRPIJP }\end{aligned}$ \\
\hline Ekspor ban Indonesia ke Australia & XRPIAUS & $\begin{aligned}= & \mathrm{j} 0+\mathrm{j} 1^{*} \text { DHXRPIAU + j2*LNTRPUSD + } \\
& \mathrm{j} 3^{*} \text { RUPAHTRI + j4*HRUBSBR + j5*DQRRIDN + } \\
& \mathrm{j} 6^{*} \text { QRPAUS + j7*L2RGDPAUS + j8*LXRPIAUS }\end{aligned}$ \\
\hline Ekspor ban Indonesia ke Malaysia & XRPIMAL & $\begin{aligned}= & \mathrm{k} 0+\mathrm{k} 1^{*} \text { HXRPIMA }+\mathrm{k} 2^{*} \text { L } 3 \text { NTRPUSD }+ \\
& \mathrm{k} 2^{*} \text { RUPAHTRI }+\mathrm{k} 4^{*} \text { LHRUBSBR }+\mathrm{k} 5^{*} \text { DQRPIDN } \\
& +\mathrm{k} 6^{*} \text { L2QRPMAL }+\mathrm{k} 7^{*} \text { DQAUTMAL }+ \\
& \mathrm{k} 8^{*} \text { LRGDPMAL }+\mathrm{k} 9^{*} T+\mathrm{k} 10^{*} \text { LXRPIMAL }\end{aligned}$ \\
\hline Ekspor ban Indonesia ke Filipina & XRPIFIL & 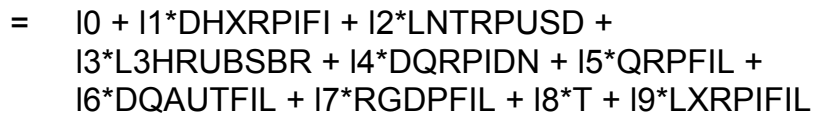 \\
\hline Nilai ekspor karet SIR Indonesia & NXSIRIDN & 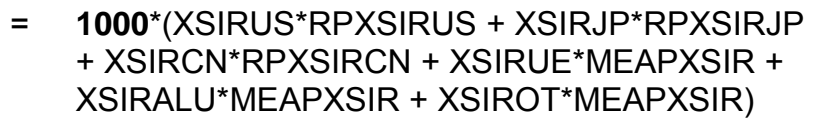 \\
\hline Nilai impor karet alam Indonesia & NMRUBIDN & $1000^{*}\left(M_{S I R}{ }^{*} R P M R U B W^{*} N T R R P U S D\right)$ \\
\hline Nilai ekspor ban Indonesia & NXRPIDN & $\begin{array}{l}\text { 1000*NTRPUSD*(XRPIUS*PXRPUS + } \\
\text { XRPIJP*PXRPJP + XRPIAUS*PXRPAUS + } \\
\text { XRPIMAL*PXRPMAL + XRPIFIL*PXRPFIL + } \\
\text { XRPIOT*MEARPXRP) }\end{array}$ \\
\hline Nilai impor ban Indonesia & NMRPIDN & 1000*(MRPIDN*MEARPMRP*NTRPUSD) \\
\hline $\begin{array}{l}\text { Neraca perdagangan karet alam } \\
\text { dan ban Indonesia }\end{array}$ & BOTSIRRP & $\begin{array}{l}(\text { NXSIRIDN + NXRPIDN) }-(\text { NMSIRIDN + } \\
\text { NMRPIDN) }\end{array}$ \\
\hline
\end{tabular}

Keterangan:

QRUB : produksi karet alam Indonesia

QSIR : produksi karet SIR Indonesia

QSSIR : Penawaran karet SIR domestik

QDSIR : Permintaan karet SIR domestik

XSIR : ekspor karet SIR Indonesia ke pasar dunia

XSTR : ekspor karet STR Thailand ke pasar dunia

XSMR : ekspor karet SMR Malaysia ke pasar dunia

XSIRUS : ekspor karet SIR Indonesia ke USA

XSIRJP : ekspor karet SIR Indonesia ke Jepang

XSIRCN : ekspor karet SIR Indonesia ke Cina

XSTRUS : ekspor karet STR Thailand ke USA

XSTRJP : ekspor karet STR Thailand ke Jepang

XSTRCN : ekspor karet STR Thailand ke Cina

XSMRUS : ekspor karet SMR Malaysia ke USA

XSMRJP : ekspor karet SMR Malaysia ke Jepang

XSMRCN : ekspor karet SMR Malaysia ke Cina

MTSNRUS : impor karet TSNR oleh USA

MTSNRJP : impor karet TSNR oleh Jepang
MTSNRCN : impor karet TSNR oleh Cina

MSIRUSI : impor karet SIR Indonesia oleh USA

MSIRJPI : impor karet SIR Indonesia oleh Jepang

MSIRCNI : impor karet SIR Indonesia oleh Cina

MSTRUST : impor karet STR Thailand oleh USA

MSTRJPT : impor karet STR Thailand oleh Jepang.

MSTRCNT : impor karet STR Thailand oleh Cina.

MSMRUSM : impor karet SMR Malaysia oleh USA.

MSMRJPM : impor karet SMR Malaysia oleh Jepang.

MSMRCNM : impor karet SMR Malaysia oleh Cina.

RPXSIRUS : harga ekspor karet SIR ke USA.

RPXSIRJP : harga ekspor karet SIR ke Jepang

RPXSIRCN : harga ekspor karet SIR ke Cina.

PRUBFM : harga karet alam tingkat petani domestik

RPMRUBW: harga riil impor karet alam di pasar dunia PFUTRUB: harga kontrak berjangka karet alam Sicom

QRPIDN : produksi ban oleh industri domestik.

DRUBRP: konsumsi karet alam industri ban domestik 
HXRPIUS : harga ban di USA di deplat (tarif impor +1) HXRPIJP : harga ban di Jepang deplat (tarif impor +1) HXRPIAU: harga ban di Australia deplat (tarif impor+1)

HXRPIMA : harga ban di Malaysia deplat (tarif impor+1)

HXRPIFI : harga ban di Filipina deplat (tarif impor +1)

XRPIUS : ekspor ban Indonesia ke USA.

XRPIJP : ekspor ban Indonesia ke Jepang.

XRPIAUS : ekspor ban Indonesia ke Australia.

XRPIMAL : ekspor ban Indonesia ke Malaysia

XRPIFIL : ekspor ban Indonesia ke Filipina

XRPIDN : ekspor ban Indonesia ke pasar dunia

PXRPUS : harga ekspor ban di pasar USA

PXRPJP : harga ekspor ban di pasar Jepang

PXRPAUS : harga ekspor ban di pasar Australia

PXRPMAL : harga ekspor ban di pasar Malaysia

PXRPFIL : harga ekspor ban di pasar Filipina

NXSIRIDN : nilai ekspor karet SIR Indonesia

NMRUBIDN : nilai impor karet alam Indonesia

NXRPIDN : nilai ekspor ban Indonesia

NMRPIDN : nilai impor ban Indonesia

BOTSIRRP : neraca perdagangan karet alam dan ban Indonesia

PRUBFM : harga karet tingkat petani domestik

RLIR : suku bunga pinjaman riil domestik

T : Tren

TRCOSTUS : biaya transpor pengapalan ke USA (USD/Container)

ITRCD : variabel dummy untuk tahun pembatasan suplai karet oleh ITRC

SHRMRUBW: pangsa impor karet TSNR Cina di dunia

QRUBTHA : produksi karet alam Thailand (ton)

AUTJPSIA : pangsa produksi automotif Jepang di Asia

NTRPUSD : nilai tukar riil Rp terhadap USD

NTYNUSD : nilai tukar Yuan terhadap USD

NTYEUSD : nilai tukar riil Yen terhadap USD

NTBATUSD : nilai tukar riil Baht terhadap USD

RPXSTRUS : harga ekspor karet STR Thailand ke

RPXSTRCN : harga ekspor karet STR ke Cina

RPXSTRJP : harga ekspor karet STR ke Jepang

RPXSMRUS : harga ekspor karet SMR ke USA
RPXSMRCN : harga ekspor karet SMR ke Cina

RPXSMRJP : harga ekspor karet SMR Jepang

RPMSIRUSI : harga impor karet SIR di USA

RPMSIRCNI : harga impor karet SIR di Cina

RPMSIRJP : harga impor karet SIR di Jepang

RPMSTRUS : harga impor karet STR di USA

RPMSTRCN : harga impor karet STR di Cina

RPMSTRJP : harga impor karet STR di Jepang

RPMSMRUS : harga impor karet SMR di USA

RPMSMRCN : harga impor karet SMR di Cina

RPMSMRJP : harga impor karet SMR di Jepang

RGDPUS : GDP riel USA (USD/kapita)

RGDPCN : GDP riil Cina (USD/kapita)

RGDPJP : GDP riil Jepang (USD/kapita)

RGDPAUS : GDP riil Australia (USD/kapita)

QRPUS : produksi industri ban di USA (ton)

QRPCN : produksi industri ban di Cina (ton)

QRPJP : produksi industri ban di Jepang (ton)

QRPAUS : produksi industri ban di Australia (ton)

QRPMAL : produksi industri ban Malaysia (ton)

QRPFIL : produksi industri ban Filipina (ton)

AUTUS : produksi industri automotif di USA (ton)

AUTJP : produksi industri automotif di Jepang

AUTAUS : produksi industri automotif di Australia

QAUTMAL: produksi industri automotif Malaysia

QAUTFIL : produksi automotif Filipina (ribu unit)

MRPW $_{\mathrm{t}}$ : impor produk karet/ban dunia (ton)

QAUTW $_{\mathrm{t}}$ : produksi automotif dunia (ribu unit)

HRUBSBR: rasio harga karet alam dengan karet sintetis

RUPAHTRI: rata-rata upah riel industri Indonesia.

RPNGASIN: harga riel gas alam di pasar dunia

QDRUB : konsumsi karet alam domestik (ton).

TFRPUS : tarif impor ban di USA (\%/tahun)

TFRPJP : tarif impor ban di Jepang (\%/tahun)

TFRPAUS : tarif impor ban di Australia (\%/tahun)

TFRPMAL : tarif impor ban di Malaysia (\%/tahun)

TFRPFIL : tarif impor ban di Filipina (\%/tahun)

TFRPIDN : tarif impor ban di Indonesia (\%/tahun)

TMRUBCN : tarif impor karet alam di Cina

$$
\text { (\%/tahun) }
$$

RPMRPIUS: harga impor ban Indonesia di USA

RPMRPIJP : hargaimpor ban Indonesia di Jepang

RPMRPIAUS : harga impor ban Indonesia di

Australia 
RPMRPIMAL : harga impor ban Indonesia di Malaysia

RPMRPIFIL : harga impor ban Indonesia di Filipina

\section{Validasi dan Simulasi Model}

Untuk mengetahui suatu model valid untuk membuat suatu simulasi kebijakan maka diperlukan validasi model dengan tujuan sejauh mana kemampuan dan keandalan model dapat mewakili perilaku dunia nyata. Kriteria statistik yang digunakan dalam memvalidasi model adalah Root Mean Squares Percent Error (RMSPE) dan Theil's Inequality Coefficients (U).

$$
\begin{aligned}
& R M S P E=\left\{\frac{1}{T} \sum_{t=1}^{T}\left(\frac{Y_{t}^{S}-Y_{t}^{a}}{Y_{t}^{a}}\right)^{2}\right\}^{1 / 2} x 100 \\
& U=\frac{\left(\frac{1}{T} \sum_{t=1}^{T}\left(Y_{t}^{S}-Y_{t}^{a}\right)^{2}\right)^{1 / 2}}{\left[\frac{1}{T} \sum_{t=1}^{T}\left(Y_{t}^{S}\right)^{2}\right]^{1 / 2}+\left[\frac{1}{T} \sum_{t=1}^{T}\left(Y_{t}^{a}\right)^{2}\right]^{1 / 2}}
\end{aligned}
$$

RMSPE $=$ Root Mean Squares Percent Error

$\mathrm{U}=$ Theil's Inequality Coefficients

$Y_{t}^{S}=$ nilai prediksi var endogen;

$Y_{t}^{a} \quad=$ nilai aktual var endogen;

$\mathrm{T} \quad=$ jumlah tahun pengamatan

Validasi diartikan seberapa dekat nilai estimasi model mengikuti nilai aktual. Semakin kecil nilai statistik RMSPE dan U Theil maka model yang digunakan akan semakin baik.

Selanjutnya dilakukan simulasi model untuk menjelaskan dampak penurunan tarif impor karet alam dan ban, dan peningkatan investasi dan relokasi industri ban ke domestik Indonesia menggunakan simulasi historis (Tabel 1). Simulasi penurunan tarif impor di negara pengimpor menggunakan empat skenario mulai (B1 - B4). Contoh skenario B1 adalah simulasi turunnya tarif impor ban di USA 30\%, Australia 30\%, Malaysia $50 \%$, Indonesia $50 \%$ dan tarif impor karet alam RRT tidak berubah. Simulasi peningkatan investasi dan relokasi industri ban dari USA, Jepang dan RRT ke Indonesia menggunakan tiga skenario mulai $\mathrm{C} 1$ sampai dengan C3. Contoh skenario C1 adalah simulasi peningkatan investasi industri ban domestik Indonesia 50\% disertai turunnya produksi ban menangkap relokasi industri ban ke domestik) di USA $2,5 \%$, Jepang 2,5\%, RRT 2,5\%. 
Tabel 1. Skenario Simulasi Model Perdagangan Karet Alam dan Ban Indonesia

\begin{tabular}{|c|c|c|c|c|c|}
\hline \multirow[t]{2}{*}{ Skenario Simulasi } & \multirow[t]{2}{*}{ Perubahan Variabel } & \multicolumn{4}{|c|}{ Skenario Perubahan } \\
\hline & & B1 & B2 & B3 & B4 \\
\hline \multirow{7}{*}{$\begin{array}{l}\text { Penurunan tarif impor di } \\
\text { negara pengimpor }\end{array}$} & Tarif impor produk karet di USA & $-30 \%$ & $-50 \%$ & $-30 \%$ & $-50 \%$ \\
\hline & Tarif impor produk karet di Jepang & 0 & 0 & 0 & \\
\hline & Tarif impor produk karet di Australia & $-30 \%$ & $-50 \%$ & $-30 \%$ & $-50 \%$ \\
\hline & Tarif impor produk karet di Malaysia & $-50 \%$ & $-75 \%$ & $-50 \%$ & $-75 \%$ \\
\hline & Tarif impor produk karet di Filipina & $-30 \%$ & $-50 \%$ & $-30 \%$ & $-50 \%$ \\
\hline & Tarif impor produk karet di Indonesia & $-50 \%$ & $-75 \%$ & $-50 \%$ & $-75 \%$ \\
\hline & Tarif impor karet alam di Cina & & & $-50 \%$ & $-100 \%$ \\
\hline \multirow{5}{*}{$\begin{array}{l}\text { Peningkatan investasi dan } \\
\text { relokasi industri ban } \\
\text { (USA, Jepang, Cina) } \\
\text { ke Indonesia. }\end{array}$} & & $\mathrm{C} 1$ & $\mathrm{C} 2$ & \multicolumn{2}{|c|}{$\mathrm{C} 3$} \\
\hline & Konsumsi karet alam di Indonesia & $50 \%$ & $100 \%$ & \multicolumn{2}{|c|}{$150 \%$} \\
\hline & Produksi industri ban di USA & $-2,5 \%$ & $-5,0 \%$ & \multirow{2}{*}{\multicolumn{2}{|c|}{$\begin{array}{l}-7,5 \% \\
-7.5 \%\end{array}$}} \\
\hline & Produksi industri ban di Jepang & $-2,5 \%$ & $-5,0 \%$ & & \\
\hline & Produksi industri ban di Cina & $-2,5 \%$ & $-5,0 \%$ & \multicolumn{2}{|c|}{$-7,5 \%$} \\
\hline
\end{tabular}

Penelitian ini menggunakan data seri waktu tahunan (time series) periode 1985 sampai 2015 untuk komoditas karet alam spesifikasi teknis (TSNR). Data ban Indonesia khususnya kode HS 4011 rentang dari tahun 1985 sampai dengan 2015. Data lainnya yang terkait juga menggunakan rentang waktu yang sama. Sumber data berasal dari berbagai instansi pemerintah, asosiasi, dan lembaga internasional seperti Badan Pusat Statistik, Kementerian Pertanian, Kementerian Perindustrian, Gabungan Pengusaha Karet Indonesia, Kementerian Perdagangan, UN Comtrad Statistics, International Trade Rubber Group, International Tripartite Rubber Council, Malaysian Rubber Board, Thailand Rubber Association, Japan Tyres and Manufactures Association (JATMA), Eropa Tyres and Manufactures Association (ETRMA), International
Organization of Motor Vehicle Manufacturers (OICA), Indian Tyres and Manufactures Association, World Automotive Manufactures Association, China Ministry of Trade, Australian Ministry of Commerce, Japan Ministry of Trade, USA Ministry of Trade, United State Tyres Manufacturing Association (USTMA), Australian Tyres Industries Council (ATIC).

\section{HASIL DAN PEMBAHASAN}

Secara keseluruhan hasil validasi model menunjukkan $71 \%$ dari total persamaan mempunyai nilai RMSPE kecil dari 30\%. Statistik U-Theil menunjukkan $84 \%$ dari total persamaan mempunyai nilai U-theil kecil dari 0,2. Jumlah persamaan yang mempunyai nilai $U$ theil kecil dari 0.1 mencapai $64 \%$ dari total persamaan dalam model. Berdasarkan indikator statistik tersebut, model dinilai relatif baik dan dapat digunakan untuk melakukan simulasi 
dampak yaitu: 1) penurunan tarif impor ban dan karet alam; dan 2) kombinasi peningkatan investasi industri ban domestik dengan relokasi industri ban dari USA, Jepang dan RRT ke domestik. Kedua simulasi menjadi perhatian penting dalam penelitian.

\section{Dampak penurunan tarif impor terhadap perdagangan karet alam} dan ban Indonesia di pasar dunia.

Hasil simulasi penurunan tarif impor ban (B1 dan B2) memberikan dampak peningkatan produksi dan ekspor ban Indonesia tetapi impor ban domestik juga meningkat relatif besar. Ekspor ban Indonesia ke berbagai negara meningkat kecuali ke pasar Australia. Peningkatan produksi ban mendorong kenaikan konsumsi karet oleh industri ban domestik sehingga pasar bahan baku berupa karet alam menjadi lebih kompetitif dan atraktif di pasar domestik yang ditunjukkan oleh peningkatan permintaan karet SIR domestik dan harga karet alam tingkat petani juga mengalami kenaikan (Tabel 2). Respon ekspor ban tersebut sesuai dengan Asirvatham, J. et.al (2017) menyatakan bahwa liberalisasi perdagangan melalui pemotongan tarif dan promosi FDI mempunyai dampak positif terhadap ekspor negara Asean-5
(Indonesia, Malaysia, Singapura, Thailand, Filipina). Arapova, E.Y (2017) juga memaparkan bahwa efek integrasi ekonomi ASEAN diantaranya melalui penghapusan hambatan tarif memengaruhi volume ekspor negara anggota ASEAN termasuk agricultural products dan rubber based products.

Hasil simulasi yang cukup menarik adalah jika dilakukan penurunan tarif impor ban negara pengimpor termasuk Indonesia memberikan dampak ekspor karet alam (khususnya karet spesifikasi teknis) yang berbeda antara Indonesia dengan Thailand dan Malaysia. Penurunan tarif impor ban meningkatkan ekspor karet SIR Indonesia ke pasar Jepang dan RRT, sebaliknya menurunkan ekspor karet STR Thailand dan karet SMR Malaysia ke pasar Jepang. Kemungkinan turunnya tarif impor ban di berbagai negara memperbesar akses pasar ban asal Jepang sehingga terjadi kenaikan ekspor. Peningkatan ekspor ban tersebut kemungkinan mendorong kenaikan produksi industri ban Jepang sehingga terjadi peningkatan impor bahan baku karet alam. Respons impor karet alam oleh importer Jepang akibat penurunan tarif tersebut lebih 
Tabel 2. Dampak Penurunan Tarif Impor terhadap Perdagangan Karet Alam dan Ban Indonesia di Pasar Dunia

\begin{tabular}{|c|c|c|c|c|c|c|c|}
\hline \multirow{2}{*}{ No } & \multirow{2}{*}{ Variabel } & \multirow{2}{*}{ Satuan } & \multirow{2}{*}{$\begin{array}{c}\text { Nilai } \\
\text { Dasar }\end{array}$} & \multicolumn{4}{|c|}{ Perubahan (\%) } \\
\hline & & & & B1 & B2 & B3 & B4 \\
\hline 1 & Produksi karet Indonesia & Ton & 3337330 & 0.01 & 0.02 & 0.003 & 0.002 \\
\hline 2 & Penawaran karet SIR domestik & Ton & 344871 & 0.06 & 0.10 & 0.18 & 0.33 \\
\hline 3 & Permintaan karet SIR domestik & Ton & 261234 & 0.13 & 0.21 & 0.14 & 0.22 \\
\hline 4 & Total Ekspor karet SIR Indonesia & Ton & 2413472 & 0.01 & 0.01 & -0.02 & -0.04 \\
\hline 5 & Ekspor Karet SIR ke USA & Ton & 572415 & 0.00 & 0.00 & 0.00 & 0.00 \\
\hline 6 & Ekspor Karet SIR ke Jepang & Ton & 371620 & 0.02 & 0.03 & 0.00 & 0.00 \\
\hline 7 & Ekspor Karet SIR ke Cina & Ton & 368533 & 0.02 & 0.03 & -0.15 & -0.29 \\
\hline 8 & Total Ekspor Karet STR Thailand & Ton & 3182116 & 0.00 & 0.00 & 0.27 & 0.52 \\
\hline 9 & Ekspor Karet STR Thailand ke USA & Ton & 204687 & 0.00 & 0.00 & 0.00 & 0.00 \\
\hline 10 & Ekspor Karet STR Thailand ke Jepang & Ton & 297807 & -0.02 & -0.03 & 0.00 & 0.00 \\
\hline 11 & Ekspor Karet STR Thailand ke Cina & Ton & 1225306 & 0.00 & -0.01 & 0.71 & 1.36 \\
\hline 12 & Total Ekspor Karet SMR Malaysia & Ton & 811623 & 0.00 & 0.00 & 0.01 & 0.02 \\
\hline 13 & Ekspor Karet SMR Malaysia ke USA & Ton & 35294 & 0.00 & 0.00 & 0.00 & 0.00 \\
\hline 14 & Ekspor Karet SMR Malaysia ke Jepang & Ton & 1734 & -0.18 & -0.29 & -0.04 & -0.03 \\
\hline 15 & Ekspor Karet SMR Malaysia ke Cina & Ton & 324440 & 0.00 & 0.00 & 0.03 & 0.05 \\
\hline 16 & Total Suplai Karet TSNR Dunia & Ton & 11274931 & 0.00 & 0.00 & 0.07 & 0.14 \\
\hline 17 & Total Impor Karet TSNR Dunia & Ton & 8276747 & 0.00 & 0.00 & 1.10 & 2.20 \\
\hline 18 & Ekses Suplai Karet TSNR Dunia & Ton & 2998184 & 0.00 & -2.76 & -2.76 & -5.54 \\
\hline 19 & Total Impor Karet TSNR USA & Ton & 1015342 & 0.00 & 0.00 & 0.00 & 0.00 \\
\hline 20 & Total Impor Karet TSNR Jepang & Ton & 736124 & 0.00 & 0.00 & 0.00 & 0.00 \\
\hline 21 & Total Impor Karet TSNR Cina & Ton & 2331402 & 0.00 & 0.00 & 3.90 & 7.80 \\
\hline 22 & Harga Karet Tingkat Petani & $\mathrm{Rp} / \mathrm{kg}$ & 19678 & 0.24 & 0.39 & 0.06 & 0.04 \\
\hline 23 & Harga Ekspor Karet SIR Indonesia & USD/kg & 2.019 & 0.00 & 0.00 & 0.00 & 0.00 \\
\hline 24 & Harga Ekspor Karet STR Thailand & Baht/kg & 65.775 & 0.00 & 0.00 & 6.74 & 13.48 \\
\hline 25 & Harga Ekspor Karet SMR Malaysia & MYR/kg & 5.318 & 0.00 & 0.00 & 5.62 & 11.24 \\
\hline 26 & Harga Karet TSNR Dunia & USD/kg & 2.685 & 0.00 & 0.00 & 0.63 & 1.25 \\
\hline 27 & Harga Kontrak Berjangka Karet Sicom & USD $/ \mathrm{kg}$ & 2.656 & 0.00 & 0.00 & 9.58 & 19.19 \\
\hline 28 & Produksi Ban Indonesia & Ton & 526700 & 0.14 & 0.22 & 0.14 & 0.23 \\
\hline 29 & Konsumsi karet industri ban domestik & Ton & 256927 & 0.14 & 0.22 & 0.14 & 0.23 \\
\hline 30 & Ekspor Ban Indonesia & Ton & 442888 & 0.36 & 0.58 & 0.36 & 0.58 \\
\hline 31 & Ekspor Ban Indonesia ke US & Ton & 141477 & 0.32 & 0.53 & 0.32 & 0.53 \\
\hline 32 & Ekspor Ban Indonesia ke Jepang & Ton & 48177 & 0.02 & 0.04 & 0.02 & 0.04 \\
\hline 33 & Ekspor Ban Indonesia ke Australia & Ton & 19465 & -0.19 & -0.32 & -0.19 & -0.32 \\
\hline 34 & Ekspor Ban Indonesia ke Malaysia & Ton & 30633 & 3.77 & 5.95 & 3.77 & 5.95 \\
\hline 35 & Ekspor Ban Indonesia ke Filipina & Ton & 17160 & 0.12 & 0.20 & 0.12 & 0.20 \\
\hline \multirow{3}{*}{36} & Impor Ban Indonesia & Ton & 62644 & 170.53 & 255.78 & 170.52 & 255.77 \\
\hline & & & & \multicolumn{4}{|c|}{ Perubahan (Nilai) } \\
\hline & Kinerja Neraca Perdagangan & & & B1 & B2 & B3 & B4 \\
\hline 37 & Nilai Ekspor Karet SIR Indonesia & Triliun Rp & 58.930 & 0.010 & 0.010 & 0.250 & 0.500 \\
\hline 38 & Nilai Impor Karet TSNR Indonesia & Milyar Rp & 75.310 & 0.000 & 0.010 & 0.630 & 1.240 \\
\hline 39 & Nilai Ekspor Ban Indonesia & Triliun Rp & 9.116 & 0.035 & 0.056 & 0.035 & 0.056 \\
\hline 40 & Nilai Impor Ban Indonesia & Triliun Rp & 0.781 & 1.422 & 2.133 & 1.422 & 2.133 \\
\hline 41 & BoT (Nilai Ekspor - Nilai Impor) & Triliun Rp & 67.190 & -1.380 & -2.070 & -1.140 & -1.580 \\
\hline
\end{tabular}

Sumber: hasil simulasi model menggunakan software SAS/ETS 
negara pengimpor disertai dengan penurunan tarif impor karet alam RRT (skenario B3 dan B4), memberikan dampak peningkatan permintaan karet TSNR dunia sebagai akibat dari kenaikan impor dari negara pengimpor besar karet TSNR khususnya RRT dalam rentang $3,90 \%$ sampai $7,80 \%$. Kenaikan impor karet alam RRT mendorong produksi industri manufaktur mengingat ekonomi RRT sangat ditopang oleh industri manufaktur. Namun terdapat keraguan kenaikan impor input material oleh RRT dalam periode akan datang karena ekonomi RRT mengalami perlambatan (slowdown) dan melakukan perubahan ke keseimbangan baru (rebalancing) untuk mencapai pertumbuhan ekonomi yang lebih berkelanjutan (Inoue, et al, 2015; Kawai \& Lee, 2015). Alasan mengapa pertumbuhan ekonomi RRT melambat (slowdown) antara lain: 1) industri manufaktur menyumbang 59\% terhadap PDB RRT dan perlambatan ekonomi Uni Eropa, Jepang dan Korea Selatan menyebabkan turunnya ekspor RRT serta memicu perlambatan global; 2) sektor real estate menyumbang 25$30 \%$ terhadap PDB RRT. Penurunan harga perumahan telah merugikan investor dan memicu gagal bayar oleh pengembang real estate; dan 3) penurunan sektor automotif dan konstruksi mengurangi permintaan besi dan baja padahal RRT adalah produsen terbesar baja. RRT mulai beralih dari export led-growth ke consumption ledgrowth yang lebih berkelanjutan.

Kenaikan permintaan karet alam mampu menaikkan harga impor karet TSNR di pasar dunia, harga kontrak berjangka karet di pasar Bursa Singapura, harga ekspor karet STR Thailand dan karet SMR Malaysia sebagaimana hasil skenario simulasi B3 dan B4 (Tabel 2). Kenaikan permintaan tersebut tidak berdampak terhadap harga ekspor karet SIR Indonesia yang cenderung stabil, begitu juga harga karet alam tingkat petani domestik.

Pada tingkat industri, hasil simulasi penurunan tarif impor memberikan dampak terhadap peningkatan produksi ban Indonesia yang diikuti dengan semakin meningkatnya konsumsi karet alam oleh industri ban domestik serta ekspor ban Indonesia sebagaimana skenario simulasi B3 dan B4 pada Tabel 2. Peningkatan ekspor ban Indonesia terjadi ke semua negara tujuan ekspor seperti AS, Jepang, Malaysia dan Filipina kecuali ke pasar Australia. Turunnya ekspor ban Indonesia ke 
pasar Australia kemungkinan terkait dengan efek substitusi dengan ban asal impor negara pesaing pada saat harga menurun akibat pemotongan tarif impor. Dampak positif dari deregulasi tarif impor tersebut sesuai dengan Arianti \& Lubis (2011) bahwa pasar industri berbasis karet Indonesia memiliki tingkat integrasi relatif tinggi di seluruh negaranegara di kawasan ASEAN melalui liberalisasi perdagangan. Erwidodo (1999) juga memaparkan bahwa skema dalam perjanjian perdagangan dalam Putaran Uruguay secara substansi menghasilkan penurunan tarif. Penurunan tarif di antara produk ekspor utama akan memberikan peningkatan akses pasar bagi para eksportir Indonesia.

Simulasi ini juga memberikan dampak defisit terhadap neraca perdagangan karet alam dan ban Indonesia dari 1,38 menjadi 2,07 triliun rupiah (skenario B1 dan B2) dan dari 1,14 menjadi 1,58 triliun rupiah (skenario B3 dan B4). Defisit tersebut lebih disebabkan pembukaan pasar ban domestik melalui penurunan tarif impor sehingga terjadi peningkatan relatif besar nilai impor ban Indonesia dari berbagai negara.

\section{Dampak peningkatan investasi dan} relokasi industri ban USA, Jepang, RRT ke domestik

Industri ban di Indonesia ditujukan untuk memenuhi permintaan ban automotif domestik dan ekspor. Pangsa ekspor ban Indonesia mencapai $76 \%$ sampai $80 \%$ dari total produksi. Ratarata produksi ban automotif domestik periode 2007 sampai 2015 mencapai 494.612 ton dengan pertumbuhan $3,47 \%$. Selama periode tersebut industri ban domestik menyerap karet alam ratarata sebesar 243.478 ton dengan pertumbuhan $1,42 \%$ (Kemenperin, 2017a). Perkembangan industri ban domestik begitu lambat dapat dikaitkan dengan rendahnya investasi baru. Penanaman modal PMDN pada sektor industri karet dan plastik domestik periode 2012-2015 hanya rata-rata sebesar Rp 2,89 triliun dengan pangsa $4,78 \%$ terhadap penanaman modal PMDN sektor industri. Pada periode yang sama penanaman modal asing rata-rata sebesar USD 592 juta atau setara $\operatorname{Rp~8,46~triliun~dengan~pangsa~}$ $4,67 \%$ terhadap penanaman modal PMA pada sektor industri (Kemenperin, 2017b). Frankel (2016) dan Thorbecke (2017) menyatakan pelemahan 
perlahan arus perdagangan manufaktur global berkolerasi dengan melambatnya investasi masuk bersih (net investment inflow) periode 2010 sampai 2015 ke negara-negara emerging market dan developing economies. Promosi investasi pada industri ban domestik kemungkinan diperlukan untuk mendorong dan mempercepat posisi Indonesia sebagai basis produksi dan ekspor ban kenderaan ke berbagai negara.

Hasil simulasi (C1 dan C2) memberikan dampak terhadap kenaikan produksi karet alam Indonesia sebesar $3,38 \%$ sampai $7,14 \%$, begitu juga ekspor karet SIR Indonesia meningkat dari $1,89 \%$ sampai $3,99 \%$. Sebaliknya ekspor karet SMR Malaysia dan karet STR Thailand mengalami penurunan. Dampak terhadap peningkatan ekspor karet SIR Indonesia tersebut sesuai dengan hasil penelitian lain yang menunjukkan bahwa FDI memberikan dampak jangka panjang yang positif terhadap ekspor Indonesia tetapi dalam jangka pendek memberikan dampak negatif (Safitriani, 2014). Sharma \& Kaur (2013) menunjukkan hubungan dua arah antara investasi langsung FDI dan ekspor atau impor pada perekonomian India. Di Cina terdapat hubungan yang searah antara investasi langsung FDI dengan ekspor/impor. Ameer \& Xu (2017) juga menunjukkan bahwa terdapat hubungan positif satu arah antara inward FDI dengan investasi domestik dalam jangka panjang.

Simulasi skenario C1 dan C2 berdampak cenderung menurunkan permintaan karet alam di pasar dunia sebagai akibat dari relokasi industri ban ke Indonesia (host country) yang memotong produksi ban negara asal (home country) dalam kisaran 2,5\%$5,0 \%$. Walaupun demikian harga impor karet TSNR di pasar dunia cenderung stabil. Transmisi harga di pasar dunia dan kuatnya dorongan permintaan domestik memberikan dampak kenaikan harga karet alam tingkat petani domestik relatif besar dalam rentang 74,07\% sampai $156,55 \%$ sebagaimana simulasi C1 dan C2 pada Tabel 3. Jika dikonversikan dengan harga bahan olah karet rakyat (bokar) mengalami kenaikan harga sebesar $R p 11.984$ sampai Rp 17.631 per kilogram bokar. 
Tabel 3. Dampak Kebijakan Investasi dan Relokasi Industri Karet Alam dan Ban dari USA, Jepang, dan RRT ke Indonesia

\begin{tabular}{|c|c|c|c|c|c|c|}
\hline \multirow{2}{*}{ No } & \multirow{2}{*}{ Variabel } & \multirow{2}{*}{ Satuan } & \multirow{2}{*}{$\begin{array}{c}\text { Nilai } \\
\text { Dasar }\end{array}$} & \multicolumn{3}{|c|}{ Perubahan (\%) } \\
\hline & & & & C1 & C2 & C3 \\
\hline 1 & Produksi karet Indonesia & Ton & 3337330 & 3.38 & 7.14 & 10.90 \\
\hline 2 & Penawaran karet SIR domestik & Ton & 344871 & 19.49 & 41.18 & 62.87 \\
\hline 3 & Permintaan karet SIR domestik & Ton & 261234 & 42.32 & 89.21 & 136.10 \\
\hline 4 & Total Ekspor karet SIR Indonesia & Ton & 2413472 & 1.89 & 3.99 & 6.09 \\
\hline 5 & Ekspor Karet SIR ke USA & Ton & 572415 & 0.49 & 1.04 & 1.59 \\
\hline 6 & Ekspor Karet SIR ke Jepang & Ton & 371620 & 5.05 & 10.69 & 16.32 \\
\hline 7 & Ekspor Karet SIR ke Cina & Ton & 368533 & 6.49 & 13.74 & 20.98 \\
\hline 8 & Total Ekspor Karet STR Thailand & Ton & 3182116 & -1.01 & -2.14 & -3.28 \\
\hline 9 & Ekspor Karet STR Thailand keUSA & Ton & 204687 & -2.00 & -4.12 & -6.26 \\
\hline 10 & Ekspor Karet STR Thailand keJepang & Ton & 297807 & -5.44 & -11.52 & -17.70 \\
\hline 11 & Ekspor Karet STR Malaysia keCina & Ton & 1225306 & -0.97 & -2.06 & -3.16 \\
\hline 12 & Total Ekspor Karet SMR Malaysia & Ton & 811623 & -0.39 & -0.83 & -1.27 \\
\hline 13 & Ekspor Karet SMR Malaysia ke USA & Ton & 35294 & -0.50 & -1.02 & -1.55 \\
\hline 14 & Ekspor Karet SMR Malaysia ke Jepang & Ton & 1734 & -64.71 & -137.05 & -210.65 \\
\hline 15 & Ekspor Karet SMR Malaysia ke Cina & Ton & 324440 & -0.58 & -1.24 & -1.89 \\
\hline 16 & Total Suplai Karet TSNR Dunia & Ton & 11274931 & 0.09 & 0.19 & 0.29 \\
\hline 17 & Total Permintaan Karet TSNR Dunia & Ton & 8276747 & -0.20 & -0.40 & -0.60 \\
\hline 18 & Ekses Suplai Karet Alam Dunia & Ton & 2998184 & 0.88 & 1.81 & 2.73 \\
\hline 19 & Total Impor Karet TSNR USA & Ton & 1015342 & -0.73 & -1.46 & -2.18 \\
\hline 20 & Total Impor Karet T & Ton & 736124 & -0.76 & -1.53 & -2.30 \\
\hline 21 & Total Impor Karet TSNR Cina & Ton & 2331402 & -0.15 & -0.29 & -0.44 \\
\hline 22 & Harga Karet Tingkat Petani & $\mathrm{Rp} / \mathrm{kg}$ & 19678 & 74.07 & 156.55 & 239.04 \\
\hline 23 & Harga Ekspor Karet SIR Indonesia & USD/kg & 2.019 & -0.08 & -0.17 & -0.25 \\
\hline 24 & Harga Ekspor Karet STR Thailand & Baht/kg & 65.775 & -0.26 & -0.51 & -0.77 \\
\hline 25 & Harga Ekspor Karet & MYR/kg & 5.318 & -0.21 & -0.43 & -0.64 \\
\hline 26 & Harga Impor Karet TSNR Dunia & USD/kg & 2.685 & 0.38 & 0.80 & 1.21 \\
\hline 27 & Harga kontrak berjangka karet Sicom & USD/kg & 2.656 & -0.01 & 0.02 & 0.06 \\
\hline 28 & Produksi Ban Indonesia & Ton & 526700 & 43.03 & 90.70 & 138.38 \\
\hline 29 & Konsumsi karet industri ban domestik & Ton & 256927 & 50.00 & 100.00 & 150.00 \\
\hline 30 & Ekspor Ban Indonesia & Ton & 442888 & 1.41 & 3.00 & 4.58 \\
\hline 31 & Ekspor Ban Indonesia k & Ton & 141477 & 0.39 & 0.78 & 1.16 \\
\hline 32 & Ekspor Ban Indonesia ke Jepang & Ton & 48177 & 8.06 & 17.17 & 26.28 \\
\hline 33 & Ekspor Ban Indonesia ke Australia & Ton & 19465 & 1.12 & 2.39 & 3.65 \\
\hline 34 & Ekspor Ban Indonesia ke Malaysia & Ton & 30633 & 1.94 & 4.14 & 6.33 \\
\hline 35 & Ekspor Ban Indonesia ke Filipina & Ton & 17160 & 5.92 & 12.61 & 19.31 \\
\hline \multirow[t]{3}{*}{36} & Impor Ban Indonesia & Ton & 62644 & -16.53 & -34.87 & -53.22 \\
\hline & Kinerja Neraca Perdagangan & & & \multicolumn{3}{|c|}{ Perubahan (nilai) } \\
\hline & & & & C1 & $\mathrm{C} 2$ & C3 \\
\hline 37 & Nilai Eksp & Triliun Rp & 58.930 & 0.950 & 2.000 & 3.040 \\
\hline 38 & Nilai Impor Karet TSNR Indonesia & Miliar Rp & 75.310 & 0.330 & 0.680 & 1.020 \\
\hline 39 & Nilai Ekspor Ban Indonesia & Triliun Rp & 9.116 & 0.144 & 0.305 & 0.466 \\
\hline 40 & Nilai Impor Ban Indonesia & Triliun Rp & 0.781 & -0.183 & -0.388 & -0.593 \\
\hline 41 & BoT (Nilai Ekspor - Nilai Impor) & Triliun Rp & 67.190 & 1.270 & 2.690 & 4.090 \\
\hline
\end{tabular}

Sumber: hasil simulasi model menggunakan software SAS/ETS

Keterangan:

C1 : konsumsi karet SIR domestik naik $50 \%$ dan produksi ban USA, Jepang, Cina turun $2.5 \%$

C2 : konsumsi karet SIR domestik naik $100 \%$ dan produksi ban USA, Jepang, Cina turun $5,0 \%$

C3 : konsumsi karet SIR domestik naik $150 \%$ dan produksi ban USA, Jepang, Cina turun 7,0\% 
Sebagai pembanding, bahwa harga bokar petani karet periode 2014-2017 rata-rata Rp7.000 sampai $\operatorname{Rp} 7.500$ per kilogram (Kementan, 2018). Kenaikan harga tersebut didorong oleh terjadinya peningkatan permintaan karet SIR di pasar domestik sebesar $42,32 \%$ sampai $89,21 \%$.

Pada tingkat industri, simulasi C1 dan C2 memberikan dampak terhadap kenaikan produksi ban yang diikuti oleh kenaikan ekspor ban Indonesia ke berbagai negara. Hal yang berbeda ditemukan Kahfi (2016) bahwa investasi (diukur dari $F D I$ inflow) tidak signifikan memengaruhi ekspor produk manufaktur Indonesia. Rahmaddi \& Ichihashi (2013) menjelaskan bahwa peranan investasi langsung asing (FDI) pada sektor manufaktur Indonesia hanya pada sektor tertentu. Sjöholm (2016) menambahkan bahwa peningkatan investasi (FDI) meningkatkan nilai tambah bagi Indonesia melalui efek positif dari kenaikan nilai tambah lebih tinggi dan juga bagi perusahaan lokal.

Peningkatan investasi FDI berkontribusi terhadap perubahan struktur ekonomi dan dengan nilai tambah yang lebih tinggi mendorong kenaikan investasi, pajak dan upah.
Lipsey \& Sjöholm (2010) menegaskan bahwa dari survei literatur menunjukkan bahwa investasi (FDI) meningkatkan pertumbuhan ekonomi, ekspor, upah, dan kesempatan kerja bagi Indonesia. Menarik investasi masuk (FDI) dengan persaingan global yang meningkat, mungkin perlu belajar dari Asia Timur melalui perbaikan kelembagaan, tenaga kerja, dan keterbukaan perdagangan.

Hasil skenario simulasi C3 memberikan dampak terhadap peningkatan produksi karet alam Indonesia, begitu juga ekspor karet SIR Indonesia. Sebaliknya ekspor karet SMR Malaysia dan karet STR Thailand mengalami penurunan sebagaimana pada Tabel 3. Permintaan karet alam dunia mengalami penurunan sebagai akibat dari relokasi industri ban ke Indonesia (host country) yang memotong produksi ban negara asal (home country) dalam kisaran 7,5\%. Walaupun permintaan karet alam dunia dan harga ekspor cenderung menurun namun harga karet alam tingkat petani domestik mengalami kenaikan relatif besar mencapai $239,04 \%$. Hal ini akibat dari dorongan permintaan karet alam domestik paralel dengan kenaikan kapasitas industri ban akibat investasi dan relokasi industri ke domestik. Jika 
dikonversikan dengan harga bahan olah karet rakyat (bokar) maka mengalami kenaikan harga tingkat petani sebesar Rp23.348/kg bahan olah karet (bokar).

Selanjutnya simulasi ini memberikan dampak terhadap kenaikan produksi dan ekspor ban Indonesia ke berbagai negara seperti AS, Jepang, Australia, Malaysia dan Filipina. Simulasi C3 cenderung memperbesar surplus neraca perdagangan karet alam dan ban Indonesia.

\section{KESIMPULAN DAN REKOMENDASI}

\section{KEBIJAKAN}

Penurunan tarif impor ban di negara pengimpor memberikan dampak menguntungkan ekspor karet alam Indonesia ke pasar Jepang dan RRT termasuk peningkatan produksi dan ekspor ban Indonesia serta memberikan dampak tidak menguntungkan ekspor karet alam Thailand dan Malaysia. Kombinasi antara penurunan tarif impor ban dengan penurunan tarif impor karet alam RRT memberikan dampak tidak menguntungkan produksi dan ekspor karet alam Indonesia ke pasar RRT serta memberikan dampak lemah terhadap perbaikan harga karet alam tingkat petani domestik. Penurunan tarif tersebut lebih menguntungkan ekspor karet alam Malaysia dan Thailand.
Peningkatan investasi dan relokasi industri ban dari USA, Jepang dan RRT ke domestik memberikan dampak besar meningkatkan produksi dan ekspor ban Indonesia, konsumsi karet alam oleh industri domestik, dan menurunkan impor ban dari berbagai negara. Peningkatan investasi dan relokasi industri ban ke domestik juga memberikan dampak meningkatkan produksi dan ekspor karet alam Indonesia, serta harga karet alam tingkat petani domestik. Peningkatan harga karet alam tingkat petani domestik lebih dominan disebabkan kenaikan permintaan karet alam di pasar domestik. Dampak ini menunjukkan bahwa investasi dan relokasi industri ke domestik mendorong pasar bahan baku karet alam domestik menjadi lebih kompetitif dan atraktif.

Peningkatan investasi dan relokasi industri ban dari USA, Jepang dan RRT ke domestik memberikan dampak meningkatkan nilai ekspor karet alam dan ban Indonesia dan menurunkan nilai impor ban Indonesia dari berbagai negara sehingga neraca perdagangan karet alam dan ban Indonesia mengalami surplus.

Perlu melakukan perundingan dan kesepakatan perdagangan bebas 
(deregulasi tarif) dengan berbagai negara yang mengimpor karet alam dan sekaligus pengekspor ban. Walaupun situasi tarif impor ban berlaku telah lebih rendah (4-5\%) namun respon tarif mampu meningkatkan ekspor ban Indonesia dan negara pengekspor lainnya ke berbagai negara. Efek umpan balik yang diharapkan dari saran kebijakan ini adalah peningkatan permintaan turunan (derive demand) bahan baku karet alam oleh industri manufaktur ban di berbagai negara yang memberikan peluang peningkatan ekspor karet alam Indonesia.

Deregulasi kombinasi tarif impor ban negara pengimpor dan tarif impor karet alam RRT berdampak kurang menguntungkan ekspor karet alam Indonesia ke pasar RRT dibandingkan ekspor karet alam Thailand dan Malaysia. Pemerintah perlu mendorong petani dan industri karet remah domestik meningkatkan kualitas dan jenis karet alam terutama untuk pasar ekspor. Dominasi ekspor berupa technical specified natural rubber (TSNR) diperkaya dengan jenis latex, rubber smoke sheet, brown crepe dan compounded rubber. Perbaikan kualitas dan pengayaan jenis ekspor karet alam diharapkan memperoleh respon positif dari negara pengimpor terutama pasar RRT bila dilakukan deregulasi tarif impor. Efek umpan balik ke sektor hulu karet alam adalah penting mengorganisasikan petani karet dalam produksi dan pengolahan karet alam terutama jenis rubber smoke sheet, brown crepe dan compounded rubber agar terjadi peningkatan value added yang diterima petani dalam perdagangan karet alam Indonesia.

Peningkatan kerja sama perdagangan oleh pemerintah dan asosiasi industri untuk melakukan industrial lobbying ke negara besar pelaku industri ban dunia untuk memperkuat basis produksi dan perdagangan ban Indonesia di pasar dunia. Kerja sama tersebut difokuskan ke negara atau kelompok negara yang telah disepakati kerangka kerja sama preferential trade atau free trade seperti dengan Asia Timur dan USA untuk meningkatkan investasi internasional langsung (FDI) ataupun berupa relokasi industri ke domestik agar semakin terintegrasi dengan tyre and rubber products global value chain. Salah satu efek umpan balik yang diharapkan adalah agar pasar bahan baku karet alam menjadi lebih kompetitif dan atraktif pada level domestik untuk 
mendorong perbaikan harga karet tingkat petani.

\section{UCAPAN TERIMA KASIH}

Penulis mengucapkan terima kasih kepada Direktorat Jenderal Pendidikan Tinggi Republik Indonesia yang telah mendukung studi program doktor dengan dana beasiswa dan penelitian disertasi BPPDN pada 2013 hingga 2017. Penulis juga mengucapkan terima kasih kepada Sekolah Pascasarjana IPB yang memperjuangkan tambahan waktu hingga terkabulkan perpanjangan beasiswa selama satu tahun ke Direktorat Jenderal Pendidikan Tinggi Republik Indonesia.

\section{DAFTAR PUSTAKA}

ANRPC. (2016). Natural Rubber Trens \& Statistics. Diunduh tanggal 7 Oktober 2016 dari http://www.anrpc.org

Ameer, W and H. Xu.(2017). Relationship Between Inward Foreign Direct Investment, Domestic Investment, Formal and Informal Institutions: Evidence from China. Review of Innovation and Competitiveness, Vol 3(2), pp.83-98

Arapova, E.Y. (2017). Ex-Post Analysis of The Influence of Tarif Liberalisation on ASEAN Exports. Applied Econometrics and International Development, Vol. 17(2), pp. 135-154

Arianti, R.K, dan A.D. Lubis. (2011). Analisis daya Saing dan Kesiapan Indonesia Dalam Rangka Integrasi ASEAN: Studi kasus Automotives, Rubber Based dan Agro Based Products. Buletin Ilmiah Litbang Perdagangan, Vol 5(1), pp.1-21.

Arunwarakorn, S., K. Suthiwartnarueput, and P. Pornchaiwiseskul. (2017).
Forecasting equilibrium quantity and price on the world natural rubber market. Kasetsart Journal of Social Sciences, pp.:1-9

ASEAN. (2017). Investment Publication. Diunduh tanggal 27 Desember 2017 dari http://www.asean.org

Asirvatham, J, Rasiah, R, Thangiah, G, and N. Naghavi. (2017). Impact of Foreign Direct Investment, Imports and Tarif Deregulation on Exports Among Pioneering ASEAN Members: panel data Analysis. International Journal of Business and Society, Vol. (18(1), pp.112

BPS. (2017a). Statistik Karet (berbagai penerbitan). Diunduh tanggal 12 Maret 2017 dari http://www.bps.go.id

BPS. (2017b). Statistik Industri Besar dan Sedang (berbagai penerbitan). Diunduh tanggal 21 April 2017 dari http://www.bps.go.id

Brander , J. A. (1995). Strategic Trade Policy. National Bureau of Economic Research, Working Paper, No. 5020.

Chacholiades, M. (1978). International Trade Theory and Policy. McGrawHill Kogakusha, Ltd.

Chiang, A. C. (2000). Elements of Dynamic Optimization. Waveland Press inc. Long Grove.

Chilimoniuk, E. (2003). Strategic Trade Policy on Oligopolistic Markets. Social Science Research Network.

Effendi, Y. (2014). Asean Free Trade Agreement Implementation for Indonesian Trading Performance: A Gravity Model Approach. Buletin Ilmiah Litbang Perdagangan, Vol. 8(1), pp.73-92.

Eklund J.E. (2013). Theories of Investment: A Theoritical Review with Empirical Applications. Working Paper Series.Research Network Debate. Swedish Entrepreneurship Forum.Swedish.

Erwidodo. (1999). Effects of Trade Liberalization on Agriculture in 
Indonesia: Institutional and Structural Aspects. The CGPRT Centre. Working Paper, No 41.

Frankel, J. (2016). Understanding the global slowdown. Program on China Business Leadership and Innovation. Harvard Kennedy School.

Houck, J. P. (1992). Elements of Agricultural Trade Policies.Prospect Heights, IL: Waveland Press.

Inoue, T. D. Kaya \& H. Ohshige. (2015). The Impact of China's Slowdown on the Asia Pacific Region: An Application of the GVAR Model. World Bank Policy Research Working Paper No. 7442. Washington, DC: The World Bank.

Intriligator, M. D. (1971).Mathematical Optimization and Economic Theory. Prentice Hall London

Jorgenson, D. (1963). Capital Theory and Investment Behavior. American Econo mic Review, Vol.53, No.2 pp. 247-259

Kahfi, A. S. (2016). Determinants of Indonesia's Exports of Manufactured Products: a Panel data Analysis. Buletin IImiah Litbang Perdagangan, Vol.10(2), pp.187-202

Kawai M, \& J.W Lee. (2015). Rebalancing for Sustainable Growth. Berlin: Springer.

Kementerian Perindustrian Republik Indonesia. (2016). Laporan Pengembangan Sektor Industri. Jakarta, Indonesia.

Kementerian Perindustrian Republik Indonesia. (2017a). Laporan Pengembangan Sektor Industri. Jakarta, Indonesia.

Kementerian Perindustrian Republik Indonesia. (2017b). kebijakan Pengembangan Industri Karet Nasional. Jakarta, Indonesia.

Khin,A.A, and S. Thambiah. (2014). Forecasting Analysis of Price Behavior : A Case of Malaysian Natural Rubber Market. American-
Eurasian J.Agric.\& Environ. Sci, Vol 14(11), pp. 1187-1195.

Koo, W.W \& P.L.Kennedy. (2005). International trade and Agriculture. Blackwell Publishing,Ltd.

Koutsoyiannis, A.(1977). Theory of Econometrics. Second Edition. Macmillan Press.United Kingdom.

Lipsey, R.E., \& F. Sjöholm. (2010). FDI and Growth in East Asia: Lessons for Indonesia. Research Institute of Industrial Economics. Stockholm, Sweden IFN Working Paper No. 852.

NurHazirah, M, ShriDewi,A, and $\mathrm{H}$. Abdullah. (2016). An Econometric Analysis of Natural Rubber Market in Malaysia. International Journal of Environmental \& Agriculture Research, Vol 2(6). pp.29-37

Pindyck, R.S. \& D.L. Rubinfeld. (1997). Econometrics Models and Economic Forecasts. 4, revised. McGraw-Hill International Editions. New York.

Rahmaddi, R., \& M. Ichihashi. (2013). The role of Foreign Direct Investment in Indonesia's manufacturing exports. Bulletin of Indonesian Economic Studies, Vol. 49(3), pp. 138-148.

Reimer, J. J. \& K. W. Stiegert. (2006). Evidance on Imperfect Competition and Strategic Trade Theory. Department of Agricultural \& Applied Economics. University of WisconsinMadison. Staff Paper No. 498.

Safitriani, S. (2014). Perdagangan Internasional dan Foreign Direct Investment di Indonesia. Buletin IImiah Litbang Perdagangan, Vol. 8(1), pp.93-116.

Sharma, R. and M. Kaur. (2013). Causal links between foreign direct investments and trade: A comparative study of India and China. Eurasian Journal of Business and Economics, 6 (11): 75-91.

Sitepu, R.K, \& B.M. Sinaga. (2018). Aplikasi Model Ekonometrika. IPB Press. Kota Bogor. Indonesia. 
Sjöholm, F. (2016). Foreign Direct Investment and Value Added in Indonesia. The Research Institute of Industrial Economics. Lund University. IFN Working Paper, No.1141.

Thorbecke, W. (2017). How would a slowdown in the people's republic of China affect its trading partners? ADBI Working Paper Series.No. 634. Asian Development Bank Institute.

Tweeten, L. (1992). Agricultural Trade: Principle and Policies. Boulder, Westview Press.
United Nation Comtrade. (2016). Comtrade Database Statistic.http:// www.comtrade.org/

World Bank. (2017). World Bank Database Statistic. Diunduh tanggal 12 Mei 2017 dari http:// www.world bank.org/tarif/

World Trade Organization. (2017). Tarifs Data. Diunduh tanggal 7 Desember 2017 dari http://wto.org/tarifs

Yusof, M. (1988). Malaysian Natural Rubber Market Model. Pertanika, Vol. 11(3), pp. 441-449. 